\title{
Impact of Climatic and Non-climatic Factors on Sustainable Livelihood Security in Gujarat State of India: A Statistical Exploration
}

\author{
Ajay Kumar Singh ${ }^{1} \Varangle$ \\ Jofri Issac ${ }^{2}$ \\ 'Assistant Professor (Economics), Department of Humanities and Social Sciences, DIT University, Dehradun, \\ Uttarakhand-248009 India. \\ Email: a.k.seeku@gmail.com Tel:+91-7566569201 \\ ${ }^{\circ}$ Research Fellow, Institute of Rural Management Anand (IRMA), Gujarat, India. \\ Email:jofri.issac91@gmail.com Tel: +91-7383974679
}

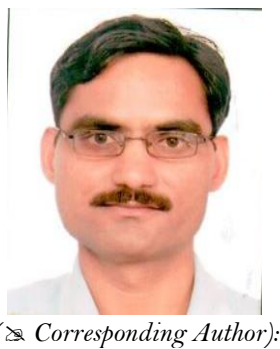

\begin{abstract}
The present study estimates the district-wise sustainable livelihood security index (SLSI) in Gujarat using Composite Z-score technique during 2000-2011. It considers SLSI as an integrated index of ecological security index (ESI), economic efficiency index (EEI) and social equity index (SEI). Accordingly, it applies linear and non-linear regression models to measure the impact of different climatic factors (i.e., maximum temperature, minimum temperature and precipitation) in winter, spring, summer and autumn seasons on SLSI, ESI, EEI and SEI. It shows that SLSI, ESI, EEI and SEI are varied across districts due to high diversity in socio-economic and ecological factors, and climatic change in Gujarat. Empirical results based on linear and non-linear regression models imply that climatic factors in different weather seasons have a negative and significant impact on SLSI, ESI, EEI and SEI. So, sustainable livelihood security (SLS) would be in an alarming position due to climate change, urbanization, population growth and industrialization in Gujarat. Thus, policy makers need to adopt an effective and conducive policy to mitigate the adverse effects of those factors which have a negative impact on sustainable livelihood security. Hence, this study provides several practical and viable policy suggestions to increase the SLS in Gujarat and other Indian states.
\end{abstract}

Keywords: SLSI, ESI, EEI, SEI, Gujarat.

Citation | Ajay Kumar Singh; Jofri Issac (2018). Impact of Climatic and Non-climatic Factors on Sustainable Livelihood Security in Gujarat State of India: A Statistical Exploration. Agriculture and Food Sciences Research, 5(1): 30-46.

History:

Received: 19 March 2018

Revised: 6 April 2018

Accepted: 9 April 2018

Published: 12 April 2018

Licensed: This work is licensed under a Creative Commons

Attribution 3.0 License $(\mathrm{cc}) \mathbf{E Y}$

Publisher: Asian Online Journal Publishing Group
Contribution/Acknowledgement: Both authors contributed to the conception and design of the study.

Funding: This study received no specific financial support.

Competing Interests: The authors declare that they have no conflict of interests.

Transparency: The authors confirm that the manuscript is an honest, accurate, and transparent account of the study was reported; that no vital features of the study have been omitted; and that any discrepancies from the study as planned have been explained.

Ethical: This study follows all ethical practices during writing.

\section{Contents}

1. Introduction

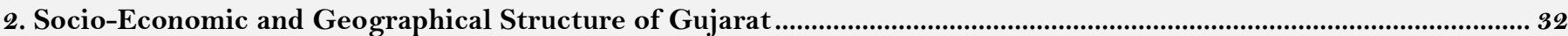

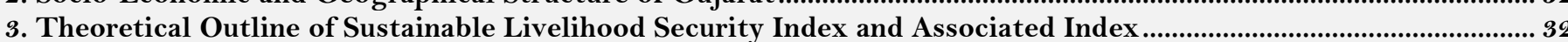

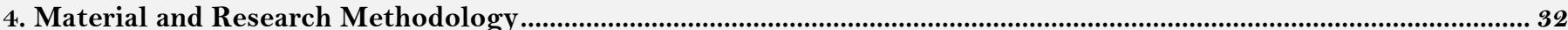

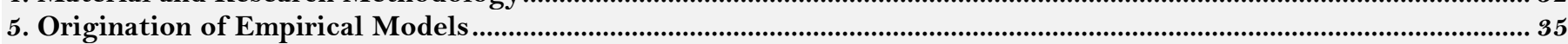

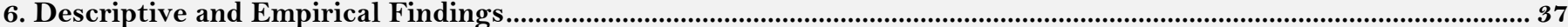

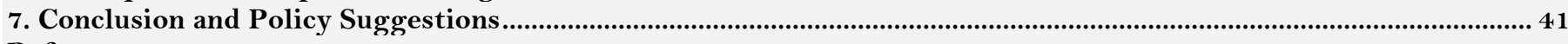

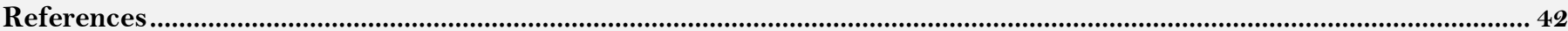




\section{Introduction}

Over and above the economic and policy factors, and climate change will affect the sustainable livelihood security $(S L S)$ of poor people due to their inadequate adaptation and lower coping capabilities in developing economies. SLS is a key focus area for researchers and policy makers in developing economies [1]. Also, it became a central research area for international development agencies in the 1990s [Q]. SLS is a multi-dimensional, multiinteracting and complex phenomenon of the society [3] which varies across individual, household, region, states and country. Thus identification of $S L S$ is very debatable and complex issue for researchers, international development organizations and global policy makers [4-8]. Livelihood is defined as the capability and assets which maintain and it make a better living standard of the peoples [2, 3, 9]. Livelihoods also include food system outcomes which contribute to food security and social welfare [10]. The capability of an individual comprises selfesteem, security, happiness, stress, vulnerability, power and exclusion [3,11]. Capability approach adopted by many research organizations to assess the situation of livelihood security of peoples [12]. Livelihood assets are categorized into natural, physical, economic or financial, human and social capital [2, 3, 13-15]. Natural capital comprises soil, forest area, irrigated area, genetic resource, hydrological cycle and water resource. Cash, credit, debit, savings, basic infrastructure, physical assets, production equipment and technology are the indicators of economic or financial capital $[14,16]$. Human capital comprises skills, knowledge, ability to labour, good health and physical capability [16]. Social capital includes the social network, social claims, social relationship, affiliations and association [16].

Livelihood security is a situation in which peoples are capable to overcome all stress which makes them socially and environmentally vulnerable and weak. While, $S L S$ is a specific situation in which peoples are capable to mitigate the negative impact of all activities such as natural disaster, climate change, economic crisis and social conflicts $[9,10,14]$. Sustainable livelihood is a necessary condition to achieve sustainable development that includes ecological security [9]. The idea of sustainable livelihood is introduced by the Brundtland Commission on Environment and Development and United Nations Conference on Environment and Development in 1992 [16]. It provides a holistic approach for poverty eradication [14]. SLS includes five indicators (i.e., diversification index, food security index, input self-sufficiency, benefit-cost ratio and women's participation in agriculture) to estimate the $S L S$ in India [12]. While, Böhringer and Jochem [17] observed three components (i.e. economic development, environmental development and social development) of SLS. SLS has significant interconnection with different indicators, thus, assessment of $S L S$ draw the attention of policy makers, government representatives, local stakeholders and international development organizations to take precautionary action. It may be useful to adopt effective policies to maintain, regulate, utilize and conservation of natural resource (i.e., land, water and air) to mention SLS. Earlier studies have estimated the sustainable livelihood security index (SLSI) as a proxy for $S L S$ in most developing economies [3-8]. However, existing researchers could not assess the influence of various socioeconomic and climatic factors on SLS using empirical models in developing economies.

\subsection{Sustainable Livelihood Security in India}

In India, SLS is negatively influenced due to overwhelming urbanization, high population growth, extensive industrialization, reduction in arable land and forest area, degradation in groundwater availability, and climate change [18]. India could not create sustainable development path due to chronic poverty, income inequality, food insecurity, ineffective and inappropriate government policies, unfair food distribution policies, and extensive utilization of natural resource in production activities. Poverty remains a major obstacle to achieve sustainable development, socio-economic development and human development in India [13, 19]. Sustainable development meets the requirements of present population without compromising the ability of future generations to meet their own needs [20-22]. It is an integration of economic, human, social, institutional, technological and environmental development. However, most economies are not giving any attention to protecting the quality and quantity of natural factors which have a positive association with SLS. Hence, it is vital to maintain and protect utilization of natural resource and other environmental factors to meet the livelihood needs of coming generation [12].

In India, agricultural production activities play a significant role to provide $S L S$, employment opportunities, food security and poverty alleviation, as around 54\% Indian workforce are engaged in agricultural [23-25]. In India, agricultural sector feeds vast population which stands second on the world. Thus, climate change and overexploitation of the natural resource would bring several threats for $S L S$, poverty eradication policies, farmer's income, job opportunities, health situation and regional-development disparities across Indian states [18, 23, 25]. India has a large pool of marginal and small farmers who are financially weak, therefore year to year variability in temperature, rainfall, precipitation, soil moisture, solar radiation would bring negative implications on the livelihood of a population $[18,23]$. Hence, agriculture is one of the significant factors which are positively associated livelihood security. Application of fertilizer in agriculture has created several barriers to maintain environmental sustainability, human health, food quality and loss of bio-diversity [18].

\subsection{Critical Research Questions and Research Objectives}

Existing studies did not estimate sustainable livelihood index (SLSI) for long-time data series in developing economies. Also, there is insufficient literature available which applied robust and rigorous empirical model to analyze the influence of certain climatic and socio-economic variables on constructed SLSI. Limited studies estimate $S L S I$ for long-time data series at the district level in India [5, 8, 26]. Nevertheless, these studies did not undertake an empirical investigation to assess the association of socio-economic and climatic factors with SLSI in India using robust and rigorous empirical model. Hence, it is essential to identify that how variability in socioeconomic variables (e.g., per capita income, urbanization, industrialization, population density, population growth, and forest area and literacy rate) and fluctuation in climatic factors (maximum and minimum temperature and precipitation) would affect the $S L S$ in India. Due to existing research gap, the present study addresses the following research questions:

- What is the association of $S L S$ with socio-economic and climatic factors in Gujarat? 
- What is the relation of $S L S$ with its components in Gujarat?

- How $S L S$ gets affected due to changing in climatic factors in Gujarat?

- Which climatic and socio-economic factors have a significant influence on SLS in Gujarat?

- How variability in socioeconomic and climatic factors would affect SLS in Gujarat in near future?

- How $S L S$ varies across districts in Gujarat?

- How and why SLS did get fluctuated during 2000-2011.

Pertinent to aforesaid research questions, the main aim of present study is to generate district-wise SLSI using a Composite Z-index technique in Gujarat. It investigates the association of SLSI, ESI, EEI and SEI with socioeconomic factors using correlation coefficient analysis technique. Thereupon, it measures the influence of climatic factors on constructed SLSI, ESI, EEI and SEI using linear and non-linear regression models.

\section{Socio-Economic and Geographical Structure of Gujarat}

Gujarat is the industrial hub of India, and its industrial sector contributes a large share in India's gross domestic product (GDP) [27]. Despite that, health and education status of Gujarat is relatively at a lower position as compared to other states like Kerala and Tamil Nadu. Only $45 \%$ of the pregnant women in Gujarat reach the hospital at the time of delivery. ${ }^{1}$ The maternal mortality rate is significantly higher in Gujarat as compared to Kerala and Tamil Nadu. So, primary health and education sector are in lower position in Gujarat. In Gujarat, total public expenditure on health sector has declined from $4.25 \%$ in $1990-95$ to $0.77 \%$ in $2005-2010 .{ }^{2}$ It infers that health facilities in Gujarat are not in a better position as compared to other states of India. ${ }^{3}$ Sex ratio is a good indicator of human development and social development in an economy. The sex ratio has also declined from 920 in 2001 to 918 in Gujarat in 2011 (Census (GoI), 2011). Gujarat has around 18,539 villages, while the state has only 7,245 primary schools. ${ }^{4}$ Thus Gujarat could not create an appropriate platform for primary education. So, Gujarat is in a poor position in social indicators, while economic growth of the state has increased due to heavy entrepreneurial activities of the people [27]. These, heavy entrepreneurial activities do have an insignificant impact on $S L S$ of peoples especially in the rural area in Gujarat. So, high diversity in $S L S$ across districts is a very critical issue for policy makers in Gujarat [5,26].

\section{Theoretical Outline of Sustainable Livelihood Security Index and Associated Index}

Numerous studies have estimated the sustainable livelihood security index (SLSI) based on primary and secondary in different economies [4, 7, 17, 28-30]. Existing studies estimate the SLSI at the micro level (i.e., individual/household) using primary data and macro level (i.e., block/district/region/state/country) using secondary data. Many indices have been developed by the scientific research community to measure the situation of human livelihood in term of SLSI [4, 11] livelihood security index (LSI), household's livelihood security index, livelihood vulnerability index $(L V I)$. Besides, scientific research community has also developed several indexes to assess the sustainable livelihood and environmental security of a region such as living planet index (LPI), ecological footprint $(E F)$, city development index $(C D I)$, human development index (HDI), environmental performance index $(E P I)$, environmental vulnerability index $(E V I)$, environmental sustainability index $(E S I)$, index of sustainable economic welfare (ISEW), genuine progress index $(G P I)$, well-being index (WI), genuine savings index $(G S I)$, and environmental adjusted domestic product $(E D P)$ [17, 20, 28-33]. These indexes integrate various components like socio-economic, demographics, livelihoods, social networks, health, food and water security and natural disaster to estimate $S L S I[7]$.

Akter and Rahman [6] estimated household's livelihood security index using economic, food, nutrition, health, education, empowerment, water and sanitation indicators of human livelihood. Ajaero [3] estimates the livelihood asset index using asset indices analytical technique, and estimate the effects of livelihood asset indices on household's livelihood status in Nigeria. Kamaruddin and Samsudin [7] used sustainable livelihood analysis framework to examine the capacity and preparedness of the rural poor in receiving entrepreneurial project channeled in Malaysia. Ponnusamy and Gupta [4] developed a sustainable livelihood index (SLI) using seven components such as environmental conservation, permanent asset creation, food security, nutritional security, input recycling, employment generation and annual income from different enterprises. Singh and Hiremath [5] estimated the SLSI, which includes composite indices of ecological security index (ESI), economic efficiency index $(E E I)$ and social equity index $(S E I)$ in India. Sajjad, et al. [8] generates block-wise SLSI with its three composite indices, i.e. ESI, EEI and SEI for agricultural sustainability in Bihar (India). Ghabru, et al. [26] also estimated district-wise SLSI using aforesaid indicators in Gujarat.

\section{Material and Research Methodology}

Brief Outline of Study Area: Gujarat is one of the leading industrialized states in India. It contributes more than $7.5 \%$ to India's GDP and $18 \%$ to India's fixed capital. It occupies $10 \%$ of India's factories and its manufacturing sector contributes $28 \%$ of its state gross domestic product. It has achieved strong annual GSDP of $10 \%$ during 2005-13, which is more than the national average during the same time period. However, Gujarat is more environmentally unsustainable state of the country as compared to other Indian states. There are several problems to sustain the livelihood security of the peoples. Therefore, the present study focusses on Gujarat. This study is based on secondary data, which includes district-wise panel data during 2000-2011. For this, eighteen districts with various economic zones of Gujarat are considered in this study. 
Data Sources and Description: Economic, food security, agriculture, education, women empowerment, ecological, climatic and geographical related variables at district level are taken from various sources like Centre Monitoring Indian Economy (CMIE) Pvt. Limited; Ministry of Agriculture (GoG); Census (GoI); Department of Animal Husbandry Dairying and Fisheries (GoG); Planning Commission (GoI); National Sample Survey Organization, Department of Statistics (GoI); Ministry of Statistics and Programme Implementation (GoI); Indian Meteorological Department (GoI). The SPSS, STATA, Minitab statistical software is used to construct SLSI, ESI, $E E I$, and SEI, and to run the proposed regression models. As some values are unavailable in time series, so interpolation and extrapolation techniques are applied to estimate the missing values to complete the time series $[25,34,35]$.

\subsection{Technique to Measure the Sustainable Livelihood Security Index (SLSI)}

(i) Selection of Variables: According to literature review, the selected variables have a scientific connection with SLS [36]. Also, there should not be high correlation among the variables [17]. As per the literature review, livelihood security is positively and negatively associated with different indicators, therefore, it essential to segregate undertaken variables in three categories i.e. ecological security, economic efficiency and social equity [8].

(ii) Normalization or Standardization-Index of Variables: Normalization index is a technique in which a variable can be converted into one scale i.e. $0-1[8,15,17,18,25,26,34,36-41]$. It makes individual variable as comparable across districts. If a variable is positively associated with SLS, then standardization-index is estimated as Ghabru, et al. [26]:

\section{$S I_{i d t}=\left\{\left[X_{i d t}-\operatorname{Min}\left(X_{i d t}\right)\right] /\left[\operatorname{Max}\left(X_{i d t}\right)-\operatorname{Min}\left(X_{i d t}\right)\right]\right)$}

Here, SI is standardization-index or normalization-index for $i^{\text {ih }}$ variables; $d$ is cross-sectional districts; and $t$ is time. $\operatorname{Min}\left(X_{i t t}\right)$ and $\operatorname{Max}\left(X_{i t t}\right)$ are the minimum and maximum values respectively in an individual indicator across districts $[25,34,39,40]$. The value of estimated $S I$ lies between $0-1$ for each indicator $[15,25,37,40-42]$. If the value of an indicator (e.g., population density, population growth rate, urbanization, fertilizer consumption/hectare land, infant mortality rate) is negatively associated with SLS [8] then SI is estimated using below formula [26]:

$S_{i d t}=\left\{\left[X_{i d t}-\operatorname{Max}\left(X_{i d t}\right)\right] /\left[\operatorname{Min}\left(X_{i d t}\right)-\operatorname{Max}\left(X_{i t t}\right)\right]\right)$

(iii) Weight of Arbitrary Variables: Appropriate weight to each indicator make index more scientific and rational $[15,17,18,25,34,36-41]$. It provides right interrelationship between variables. Weight of each indicator is examined as:

$W i=\{K / \sqrt{ }(\operatorname{Var}(S I))$

Here, $W_{i}$ is estimated weight $\left(0<\mathrm{W}>1\right.$ and $\left.\sum_{i=1}^{m} W i=1\right)$ which is allotted to $i^{\text {ih }}$ indicator $[15,25,37,39-41]$ $\operatorname{Var}(S I)$ is statistical variation across standardization-index for all indicators [25, 34, 37, 39, 41] $]$. In Equation (3), weight shows the reputation of an individual indicator. While, $K$ is measured as:

Here, $K=\frac{1}{\left\{\sum_{i=1}^{m}\left(\frac{1}{\sqrt{\operatorname{Var}(S I)}}\right)\right\}}$

(iv) Final SLSI: SLSI is a linear sum of all standardization-index that is multiplied by estimated weight of a specific indicator $[17,18,25,36,37]$. Mathematically, it can be specified as:

$(S L S I)_{d t}=W_{1} *\left(S I \_1\right)_{d t}+W_{2} *\left(S I \_2\right)_{d t}+W_{3} *\left(S I \_3\right)_{d t}+\ldots+W_{n} *\left(S I \_n\right)_{d t}$

Here, SLSI is estimated sustainable livelihood security index; $W_{1}, W_{2}, W_{s}, \ldots W_{n}$ are the weightages for associated variables; SI_1, SI_2, SI_3...SI_n are the standardization-indexes for corresponding indicators [25, 37, $39,40]$.

\subsection{Mathematical Functional Relationship of $S L S I$ with its Associated Indicators}

As per literature review, $S L S$ is an integration of ecological security, economic efficiency and social equity [2, $4-8,11,12,17,26,30]$. Hence, SLS may be considered as a function of ecological security, economic efficiency and social equity [26]. In the present study, SLSI is defined as a relative index which covers most variables and provides the relative position of a specific district in sustainable livelihood security as compared to other districts. Hence, $S L S I$ is a function of ecological security index $(E S I)$, economic efficiency index $(E E I)$ and social equity index $(S E I)$. Mathematically, above-mentioned relationship may be expressed as:

$(S L S I)_{d t}=f\left\{(E S I)_{d t},(E E I)_{d t},(S E I)_{d t}\right)$

Here, SLSI is sustainable livelihood security index; ESI, EEI and ESI are the ecological security index, economic efficiency index and social equity index respectively; $d$ is cross-sectional districts; and $t$ is time period (2000-2011). These indicators can be indicated as:

$(E S I)_{d t}=f\left\{(P D)_{d t},(P G R)_{d t},(F A G C A)_{d t},(U R)_{d t},(C I)_{d t},(H H T)_{d t}\right)$

Here, ESI-Ecological security index; PD- Population density; PGR-Population growth rate; FAGCA-Ratio of forest area with gross cropped area; UR-Urbanization rate; CI-Cropping intensity; and HHT-Households having toilets.

$(E E I)_{d t}=f\left\{(P C A M P)_{d t}(F G Y)_{d t},(G I A G C A)_{d t},(F C P H L)_{d t},(P C D D P)_{d t},(A O P H L)_{d t}\right)$

Here, EEI- Economic efficiency index; PCAMP-Per capita availability of milk production; FG - Food-grain yield; GIAGCA- Ratio of gross irrigated area with gross cropped area; FCPHL-Fertilizer consumption/hectare land; PCDDP- Per capita district domestic product; and $A O P H L$ - Agriculture output/hectare land.

$(S E I)_{d t}=f\left\{(L R)_{d t},(F L R)_{d t},(H H E A)_{d t},(P H A S W)_{d t},(I M R)_{d t},(B R)_{d t}\right)$

Here, SEI- Social equity index; LR- Literacy rate; FLR-Female literacy rate; HHEA-Households having electricity accessibility; PHASW-Population having accessibility to safe water; IMR-Infant mortality rate; and $B R-$ Birth rate. ESI, EEI and SEI would be linear sum of standardization-index or normalization-index which is multiplied by assigned weight of associated variable that is estimated as:

$(E S I)_{d t}=\mathrm{W}_{1} *\left(P D \_S I\right) d t+\mathrm{W}_{2}^{*}\left(P G R \_S I\right)_{d t}+\mathrm{W}_{3} *\left(F A G C A \_S I\right)_{d t}+\mathrm{W}_{4} *\left(U R \_S I\right)_{d t}+\mathrm{W}_{5} *\left(C I \_S I\right)_{d t}+\mathrm{W}_{6} *\left(H H T \_S I\right) d t$ 
$(E E)_{d t}=W_{1} *\left(P C A M P_{-} S I_{d t} \quad+W_{2} *\left(F G Y_{-} S I_{d t} \quad+W_{s} *\left(G I A G C A \_S I\right)_{d t} \quad+W_{t}^{*}\left(F C P H L \_S I_{d t} \quad+W_{s}^{*}\left(P C D D P \_S I\right)_{d t}\right.\right.\right.$ $+W_{6} *\left(A O P H L \_S\right)_{d t}$ $(S E I)_{d t}=W_{1} *\left(L R \_S I\right)_{d t}+W_{2} *\left(F L R \_S I\right)_{d t}+W_{3} *\left(H H E A \_S I\right)_{d t}+W_{4} *\left(P H A S W_{-} S I\right)_{d t}+W_{s} *\left(I M R \_S I\right)_{d t}+W_{s} *\left(B R \_S I\right)_{d t}$

Here, $W_{1}, W_{2}, W_{s}, W_{4}, W_{5}$ and $W_{6}$ are the weights for related variables; SIs is the standardization-index or normalization-index for corresponding variables in Equation (10), (11) and (12). Final, SLSI would be the sum of ESI, EEI and SEI, which is assessed as:

$(S L S I)_{d t}=(E S I)_{d t}+(E E I)_{d t}+(S E I)_{d t}$

\subsection{Justification on Variables}

(a) Ecological Security Related Indicators: Ecological security is helpful to develop natural resource based economy in long-term [26]. Therefore, following variables are considered under ecological security related indicators-

1. Population density: High population density is caused to increase the additional climate vulnerability and high pressure on agricultural $[8,15,18,26,34,36,39,40,43-45]$. It also increases additional pressure on ecological variables. Ecological security is also negatively associated with extensive population density. So, high population density would be negatively associated with SLS.

2. Population growth rate: High population growth requires more natural resource to sustain basic livelihood (e.g., food, land, transport, water, air) of peoples [8, 11, 13, 15, 18, 26, 39, 40, 44, 45]. It also increases GHGs emission in the atmosphere, thus it is significant cause to increase climate change. Subsequently, high population growth is negatively associated with environmental factors and SLS.

3. Ratio of forest area with gross cropped area: Forest area is an important factor to absorb $\mathrm{CO}_{2}$ emission from human and economic activities and it mitigates the negative impact of climate change in agricultural and other production activities $[5,8,13,15,18,25,26,35,36,39,40,43,45]$. Forest area also provides the livelihood opportunity in term of hunting, wood, timber, other [1]. Also, forest area maintains the balance in ecological variables, therefore it is a better adaptable technique to mitigate the adverse effects of climate change in production activities, and thus it is helpful to increase $S L S$. Hence, the ratio of forest area with a gross sown area is used as a proxy as a crucial indicator of ecological security in this study.

4. Urbanization Rate: The association between urbanization rate and $S L S$ is complex. As urbanization is caused to increase carbon emission, therefore it is a significant contributor to increase climate change [15, 36, 40, 43$45]$. Hence, $S L S$ is negatively correlated with urbanization rate in those economies which are unable to maintain the quality and quantity of natural resource due to higher urbanization [25].

5. Cropping intensity (ratio of a gross cropped area with net sown area): Cropping intensity is a crucial indicator to increase the crop production $[8,15,18,25,26,36,39,40,43,45]$. Thus, it useful to improve the farmer's income and their livelihood security.

6. Households having toilets: Sanitation facilities are an essential component to maintain the ecological security, thus households having toilets is considered as a proxy for sanitation facility in this study.

Table-1. Description of ecological security related indicators and sources of data

\begin{tabular}{|c|c|c|c|}
\hline \multicolumn{4}{|c|}{ Ecological Security Related Indicators } \\
\hline Indicators & Unit & Symbol & Source \\
\hline Population density & Number & $P D$ & Gujarat Social Development Infrastructure Board \\
\hline Population growth rate & $\%$ & $P G R$ & $\begin{array}{l}\text { Society, General Administrative Department } \\
\text { (Planning), Government of Gujarat }\end{array}$ \\
\hline $\begin{array}{l}\text { Ratio of forest area with gross cropped } \\
\text { area }\end{array}$ & Number & $F A G C A$ & CMIE Pvt. Limited \\
\hline Urbanization & $\%$ & $U R$ & http://censusindia.gov.in/ \\
\hline $\begin{array}{l}\text { Cropping intensity (ratio of gross } \\
\text { cropped area with net sown area) }\end{array}$ & Number & $C I$ & CMIE Pvt. Limited \\
\hline Households having toilets & $\%$ & $H H T$ & http://censusindia.gov.in/ \\
\hline
\end{tabular}

Source: Author's compilation based on review of literature.

(b) Economic Efficiency Related Indicators: Economic efficiency provides the appropriate way to use of the natural and human resource through the application of technological advancement [26]. Hence, following variables are compiled to estimate the $E E I$ :

1. Per capita availability of milk production: Milk is useful to meets the nutritional security to peoples [26, 43]. So, it is useful to increase SLS.

2. Food-grain yield: Food-grain yield is useful to increase per capita availability of food-grain, thus food security and subsequently SLS [18, 26,39,40].

3. Ratio of a gross irrigated area with gross cropped area: As irrigated area has a high yielding capacity than non-irrigated area $[23,25,26,34,39,40]$. Irrigated area plays a significant role to increase agricultural production and farmer's income. Irrigated area is supportive to increase the $S L S[9,15,18,25,36]$.

4. Fertilizer consumption/Ha cropped area: Suggested consumption of fertilizer in cultivation is useful to increase the crop productivity and agricultural sustainability [23, 26, 39, 40]. However, extensive application of fertilizer in cultivation deteriorates agricultural production activities. In addition, abundant fertilizer application in cultivation is caused to increase $\mathrm{CO}_{2}$ emission in the atmosphere, thus it is caused to increase high probability for climate change [25]. Hence, SLS may decline due to extensive fertilizer application in cultivation.

5. Per capita district domestic product: Per capita income is crucial indicator to increase the food security. Food security is a prime component of SLS, thus it is helpful to maintain the livelihood security [39, 40, 43, 44]. Hence, per capita district domestic product is included to capture the influence of this factor in SLS. 
6. Agricultural output/hectare land: Agricultural output/hectare land is useful to improve the farmer's income [8]. Income of agricultural labour and landless labour also improve as agricultural output/hectare land increases. Subsequently, $S L S$ would be improve as agricultural output/hectare land increases.

Table-2. Description of economic efficiency related indicators and sources of data

\begin{tabular}{l|l|l|l}
\hline \multicolumn{1}{c}{ Indicators } & \multicolumn{1}{c}{ Unit } & \multicolumn{1}{c}{ Symbol } & \multicolumn{1}{c}{ Source } \\
\hline $\begin{array}{l}\text { Per capita availability of milk } \\
\text { production }\end{array}$ & $\begin{array}{l}\mathrm{Kg} / \\
\text { Annum }\end{array}$ & PCAMP & $\begin{array}{l}\text { Livestock Census, Department of Animal } \\
\text { Husbandry, Dairying \& Fisheries, Ministry of } \\
\text { Agriculture, GoI }\end{array}$ \\
\hline $\begin{array}{l}\text { Food-grain yield } \\
\text { Ha }\end{array}$ & $F G Y$ & $\begin{array}{l}\text { Land Use Statistics, Ministry of Agriculture, } \\
\text { Government of India, Ministry of Agriculture, GoI }\end{array}$ \\
\hline $\begin{array}{l}\text { Ratio of gross irrigated area with } \\
\text { gross cropped area }\end{array}$ & Number & GIAGCA & $\begin{array}{l}\text { Agriculture and Co-operation Department, } \\
\text { Government of Gujarat }\end{array}$ \\
\hline $\begin{array}{l}\text { Fertilizer consumption/ } \\
\text { hectare land }\end{array}$ & $\begin{array}{l}\text { Tonne/ } \\
\text { Ha }\end{array}$ & $F C P H L$ & CMIE Pvt. Limited \\
\hline Per capita district domestic product & Rs & PCDDP & Using SDP data from States of India, CMIE \\
\hline Agriculture output/ hectare land & Rs & $A O P H L$ & CMIE Pvt. Limited \\
\hline Source: Author's compilation based on review of literature. & &
\end{tabular}

(c) Social Equity Related Indicators: Social equity provides an equitable distribution of available resource, thereby present and future population can get the equal economic and social benefits from development [26].

Therefore, following variables are used to create social equity index (SEI):

1. Literacy rate: Literate population have more understanding to use available resources to achieve more benefits for livelihood security than the illiterate person $[18,25,26,36,40,43,44]$. So, it is a significant driver to increase $S L S$ for long-term.

2. Female literacy rate: Female literacy is the critical indicator of women empowerment which ensure the contribution of women in national development $[5,8,26]$. It is also useful to increase social development, thus female literacy rate is useful to increase SLS.

3. Population having electricity: Availability of electricity may be useful to increase the social development [8, 26]. Consequently, $S L S$ is positively and significantly associated with availability of electricity.

4. Population having accessibility to safe water: Safe water is useful to maintain the health status of peoples. So, SLS would be improved as availability of safe drinking water increases. In this study accessibility of safe water is used as a proxy for health indicator.

5. Infant mortality rate (rural + urban): As $S L S$ is positively associated with income, health and assets [10]. Subsequently, it is also a critical indicator of social development [26, 36]. Therefore, infant mortality rate is undertaken to capture the impact of health indicator on SLS.

6. Birth rate (rural + urban): Birth rate is a critical indicator which is highly associated with SLS. Birth rate measures the effective position of the health sector, thus birth rate is included in this study. Ghabru, et al. [26] used a number of primary health centres to create social equity index in Gujarat (India).

Table-3. Social equity related indicators and sources of data

\begin{tabular}{|c|c|c|c|}
\hline \multicolumn{4}{|c|}{ Social Equity Related Indicators } \\
\hline Indicators & Unit & Symbol & Source \\
\hline Literacy rate & $\%$ & $L R$ & \multirow[t]{2}{*}{ CMIE Pvt. Limited } \\
\hline Female literacy rate & $\%$ & $F L R$ & \\
\hline Households having electricity accessibility & $\%$ & HHEA & \multirow{2}{*}{ http://censusindia.gov.in/ } \\
\hline Population having accessibility to safe water & $\%$ & PHASW & \\
\hline Infant mortality rate & Number & $I M R$ & \multirow{2}{*}{$\begin{array}{l}\text { Health and Family Welfare Department, } \\
\text { Government of Gujarat }\end{array}$} \\
\hline Birth rate (rural + urban) & Number & $B R$ & \\
\hline
\end{tabular}

Source: Author's compilation based on review of literature.

\section{(d) Climatic Factors}

Average precipitation, maximum temperature and minimum temperature in winter, spring, summer and autumn seasons are used as climatic factors in this study [18, 25, 36, 38, 40, 43].

\section{Origination of Empirical Models}

This study assesses the impact of climatic factors on SLS and its associated indicators. So, SLSI, ESI, EEI and SEI are used as independent variables and regresses with climatic factors using linear and non-linear regression models. For this, the models are adopted from earlier studies which also uses estimated index as dependent variables to assess the impact of explanatory variables on it. Demeke, et al. [46] used estimated food security index $(F S I)$ as a dependent variable to assess the impact of socio-economic and climatic factors on it in Ethiopia. Kumar and Sharma [47] also assess the impact of climatic and non-climatic factors on estimated FSI in India. Ye, et al. [48] investigate the influence of climatic factors on estimated FSI in different climate change scenarios in China. Belloumi [49] empirically investigate the impact of socio-economic and climatic factors on estimated FSI in ESA countries. Kumar, et al. [44] examine the impact of socio-economic variables on estimated global food security index across economies. Tripathi [36] assessed the influence of socio-economic variables on estimated vulnerability index in Uttar Pradesh (India). Singh [40]; Sharma and Singh [39] also assessed the influence of climatic factors on estimated FSI in India. Also, Singh, et al. [41] used several indexes like intellectual property awareness index, science \& technological development index and socio-economic development index for empirically investigation across economies. In the present study, SLSI, ESI, EEI and SEI are considered as independent 
variables and recursively regressed with climatic factors using linear and non-linear regression models. For this, following empirical models are used:

$(S L S I)_{d t}=\beta_{o}+\beta_{t}(t t f)+\beta_{1}(\text { amaxtwise })_{d t}+\beta_{2}(\text { amaxtspse })_{d t}+\beta_{3}(\text { amaxtsuse })_{d t}+\beta_{t}(\text { amaxtause })_{d t}+\beta_{5}(\text { amintwise })_{d t}+\beta_{6}$

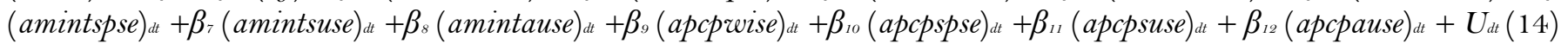

Here, $\beta_{o}$ is the constant coefficient; $\beta_{t}$ is the regression coefficient of time trend factor; $\beta_{1 \ldots} \beta_{12}$ are the regression coefficients of associated climatic factors; $U_{d t}$ is the error term; $d$ is the cross-sectional districts and $t$ is time period in Equation (14). The detail description of climatic factors is given in Table: 4.

Table-4. Description of climatic factors

\begin{tabular}{|c|c|c|c|}
\hline \multicolumn{4}{|c|}{ Description of climatic factors } \\
\hline Indicators & Unit & Symbol & Sources \\
\hline Average maximum tempereture in winter season & $\mathrm{OC}$ & amaxtwise & \multirow{12}{*}{\begin{tabular}{llr} 
Indian & \multicolumn{2}{c}{ Meteorological } \\
Department & (GoI); & Indian \\
Institute of Tropical Meteorology \\
(IITM); & and $\quad$ Geographic \\
Information & System & (GIS) \\
Software & &
\end{tabular}} \\
\hline Average maximum tempereture in spring season & $\mathrm{OC}$ & amaxtspse & \\
\hline Average maximum tempereture in summer season & $\mathrm{OC}$ & amaxtsuse & \\
\hline Average maximum tempereture in autumn season & $\mathrm{OC}$ & amaxtause & \\
\hline Average minimum tempereture in winter season & $\mathrm{OC}$ & amintwise & \\
\hline Average minimum tempereture in spring season & $\mathrm{OC}$ & amintspse & \\
\hline Average minimum tempereture in summer season & $\mathrm{OC}$ & amintsuse & \\
\hline Average minimum tempereture in autumn season & $\mathrm{OC}$ & amintause & \\
\hline Average precipitation in winter season & $\mathrm{mm}$ & apcprise & \\
\hline Average precipitation in spring season & $\mathrm{mm}$ & apcpspse & \\
\hline Average precipitation in summer season & $\mathrm{mm}$ & apcpsuse & \\
\hline Average precipitation in autumn season & $\mathrm{mm}$ & apcpause & \\
\hline
\end{tabular}

Source: Author's compilation based on review of literature.

$(E S I)_{d t}=\theta_{o}+\theta_{t}(\mathrm{ttf})+\theta_{1}(\text { amaxtwise })_{d t}+\theta_{2}(\text { amaxtspse })_{d t}+\theta_{s}(\text { amaxtsuse })_{d t}+\theta_{t}(\text { amaxtause })_{d t}+\theta_{5}(\text { amintwise })_{d t}+\theta_{6}$

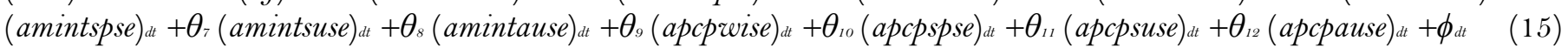

Here, $\theta_{o}$ is constant coefficient; $\theta_{t}$ is the regression coefficient of time trend factor; $\theta_{1} \ldots \theta_{12}$ are the regression coefficients of associated climatic factors; and $\phi_{d t}$ is the error term in Equation (15).

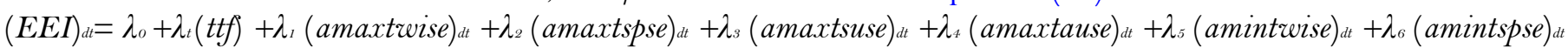
$+\lambda_{7}(\text { amintsuse })_{d t}+\lambda_{s}(\text { amintause })_{d t}+\lambda_{9}(\text { apcprise })_{d t}+\lambda_{10}(\text { apcpspse })_{d t}+\lambda_{11}(\text { apcpsuse })_{d t}+\lambda_{12}(\text { apcpause })_{d t}+€_{d t}$

Here, $\lambda_{o}$ is constant coefficient; $\lambda_{t}$ is the regression coefficient of time trend factor; $\lambda_{1} \ldots \lambda_{12}$ are the regression coefficients of related climatic factors; and $€_{d t}$ is error term in Equation (16).

$(S E I) d t=\xi_{o}+\xi_{t}(t t f)+\xi_{t}(\text { amaxtwise })_{d t}+\xi_{2}\left(\right.$ amaxtspse $_{d t}+\xi_{s}\left(\right.$ amaxtsuse $_{d t}+\xi_{t}\left(\right.$ amaxtause $_{d t}+\xi_{5}\left(\right.$ amintwise $_{d t}+\xi_{6}(\text { amintspse })_{d t}$

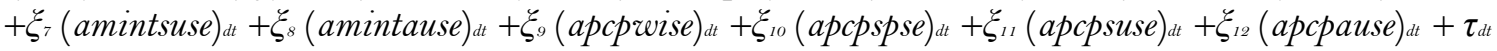

Here, $\xi_{0}$ is the constant coefficient; $\xi_{1} \ldots \xi_{12}$ are the regression coefficients of associated climatic factors; and $\tau_{d t}$ is the error term in Equation (17). For non-linear regression models, the square term of all climatic factors are included in the above-mentioned Equation (14), (15), (16) and (17) which are given as:

$(S L S I)_{d t}=\alpha_{o}+\alpha_{t}(t t f)+\alpha_{l}(\text { amaxtwise })_{d t}+\alpha_{2}\left(\text { amaxtwise }^{\wedge} 2\right)_{d t}+\alpha_{3}\left(\right.$ amaxtspse $_{d t}+\alpha_{*}\left(\text { amaxtspse }^{\wedge} 2\right)_{d t}+\alpha_{5}(\text { amaxtsuse })_{d t}+\alpha_{6}$ $\left(\text { amaxtsuse }^{\wedge} 2\right)_{d t}+\alpha_{7}(\text { amaxtause })_{d t}+\alpha_{s}\left(\text { amaxtause }^{\wedge} 2\right)_{d t}+\alpha_{9}(\text { amintwise })_{d t}+\alpha_{10}(\text { amintwise } 2)_{d t}+\alpha_{11}(\text { amintspse })_{d t}+\alpha_{12}$

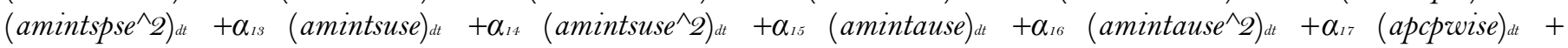
$\alpha_{1 s}(\text { apcpwise } 2)_{d t}+\alpha_{19}(\text { apcpspse })_{d t}+\alpha_{20}\left(\right.$ apcpspse $e_{d t}^{\wedge}+\alpha_{21}(\text { apcpsuse })_{d t}+\alpha_{22}\left(\text { apcpsuse }^{\wedge} 2\right)_{d t}+\alpha_{2 s}(\text { apcpause })_{d t}+\alpha_{2 t}\left(\text { apcpause } e^{\wedge} 2\right)_{d t}$ $+\infty_{d t}$

Here, $\alpha_{o}$ is the constant coefficient; $\alpha_{t}$ is the regression coefficient of time trend factors; $\alpha_{1} \ldots \alpha_{2 t}$ are the regression coefficients of corresponding variables; and $\emptyset_{d t}$ is the error term in Equation (18).

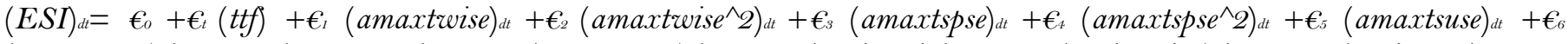

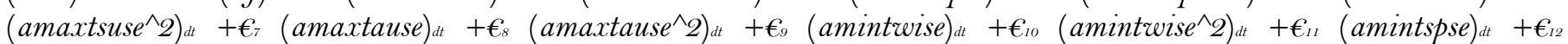

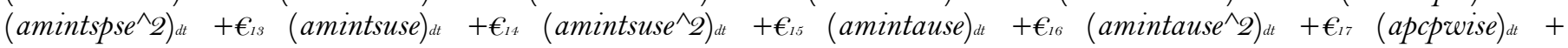
$€_{1 s}(\text { apcpwise } 2)_{d t}+\epsilon_{19}(\text { apcpspse })_{d t}+\epsilon_{20}\left(\text { apcpspse }{ }^{\wedge} 2\right)_{d t}+€_{21}(\text { apcpsuse })_{d t}+\epsilon_{22}(\text { apcpsuse } 2)_{d t}+\epsilon_{2 s}(\text { apcpause })_{d t}+€_{2 t}\left(\text { apcpause } e^{\wedge} 2\right)_{d t}+$ $\varepsilon_{d t}$

Here, $\epsilon_{0}$ is the constant coefficient; $\epsilon_{t}$ is the regression coefficient of time trend factors; $\epsilon_{l} \ldots \epsilon_{24}$ are the regression coefficients of corresponding variables; and $\varepsilon_{d t}$ is the error term in Equation (19).

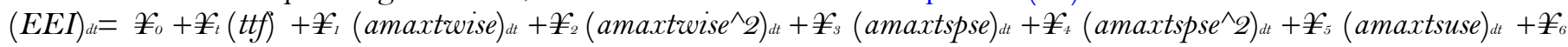

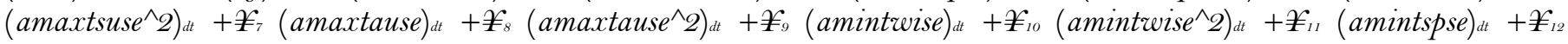

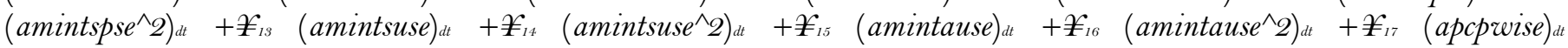

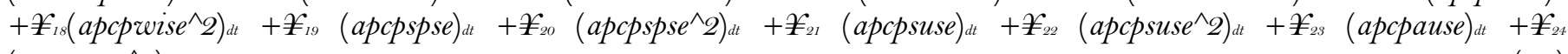
$\left(\text { apcpause }^{\wedge} 2\right)_{d t}+\mu_{d t}$

Here, $¥_{0}$ is the constant coefficient; $¥_{t}$ is the regression coefficient of time trend factors; $¥_{1} \ldots ¥_{24}$ are the regression coefficients of corresponding variables; and $\mu_{d t}$ is the error term in Equation (20).

$(S E I)_{d t}=\delta_{o}+\delta_{t}(t t f)+\delta_{l}(\text { amaxtwise })_{d t}+\delta_{2}\left(\text { amaxtwise }^{\wedge} 2\right)_{d t}+\delta_{s}(\text { amaxtspse })_{d t}+\delta_{t}\left(\text { amaxtspse } \wedge^{\wedge}\right)_{d t}+\delta_{5}(\text { amaxtsuse })_{d t}+\delta_{6}$ $\left(\text { amaxtsuse }^{\wedge} 2\right)_{d t}+\delta_{7} \quad(\text { amaxtause })_{d t}+\delta_{s} \quad\left(\text { amaxtause }^{\wedge} 2\right)_{d t}+\delta_{9} \quad(\text { amintwise })_{d t}+\delta_{10} \quad(\text { amintwise } 2)_{d t}+\delta_{11}(\text { amintspse })_{d t}+\delta_{12}$

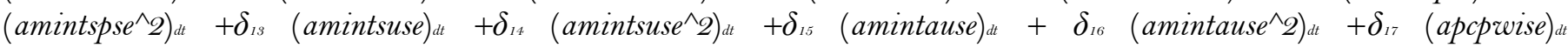
$+\delta_{1 s}\left(\text { apcpreise }{ }^{\wedge} 2\right)_{d t}+\delta_{19}(\text { apcpspse })_{d t}+\delta_{20}\left(\text { apcpspse }^{\wedge} 2\right)_{d t}+\delta_{21}(\text { apcpsuse })_{d t}+\delta_{22}\left(\text { apcpsuse }^{\wedge} 2\right)_{d t}+\delta_{2 s}(\text { apcpause })_{d t}+\delta_{24}\left(\text { apcpause } e^{\wedge} 2\right)_{d t}$ $+\psi_{d t}$

Here, $\delta_{o}$ is the constant coefficient; $\delta_{t}$ is the regression coefficient of time trend factors; $\delta_{1} \ldots \delta_{2 \star}$ are the regression coefficients of corresponding variables; and $\mu_{d t}$ is the error term in Equation (21).

\subsection{Selection of Appropriate Empirical Model}

As the sample size of this study includes 18 districts of Gujarat, which is compiled as district-wise panel data. These districts have high variation in climatic and socio-economic factors. Thus, it is essential to select an 
appropriate, consistent and viable empirical model to provide a viable statistical inference on empirical results. Firstly, Im-Pesaran-Shin test is applied to identify the existence of panel unit root in the individual time series. Variance inflation factor $(V I F)$ is estimated to recognize the multicollinearity in explanatory variables [36]. Ramsay RESET test is considered to identify that whether functional forms of linear and linear regression models is appropriate or not. Thereafter, random effect model is used to estimate the regression coefficients of explanatory variables in all model under the assumption that variation across districts is random and independent variables do have an insignificant impact on predictors [23, 25, 34, 47]. The consistency of this model is checked through Breusch-Pagan Lagrange multiplier test [25, 34, 47]. Fixed effect model is useful to capture the variation across districts and to make results unbiased. Therefore, fixed effect model is also applied, while the appropriateness of this model is recognized through Hausman specification test [23, 25, 34, 47]. Pesaran's test is also used to identify the cross-sectional independence in panel data [23, 25, 34, 47]. The presence of group-wise heteroskedasticity is recognized using Modified Wald test [25, 34, 47]. Autocorrelation is a major problem in panel data, thus the presence of autocorrelation is identified through Wooldridge test [23, 25, 34, 47]. Finally, Prais Winsten models with panels corrected standard errors estimations (PCSES) and feasible generalize least square $(F G L S)$ estimations are used to estimate the regression coefficients of explanatory variables for proposed regression models. It gives preference to PCSEs model because this model provides better results than FGLS model [23, 25, 34, 47, 50].

\section{Descriptive and Empirical Findings}

\subsection{Brief Explanation on Descriptive Results}

Figure: 1 indicates the relative position of across districts in estimated SLSI during 2000-2011. The mean values of SLSI for time periods 2000-2005 and 2006-2011, implies that Bharuch, Mahesana, Amreli, Junagadh, Sabarkantha and Rajkot have SLSI s more than 1.5, thus these districts have a relatively better position in SLS as compared to others districts in Gujarat. Kachchh, Valsad, Surendranagar, Dangs, Panchmahals and Surat have a $S L S T$ s value less than 1.40, thus districts are in relatively lower position in SLS. Jamnagar, Bhavnagar, Kheda, Vadodara, Ahmedabad and Banaskantha have SLST's value between 1.50- 1.40, thus these districts in middle position in estimated SLSI. Since the SLSI s value lies between 1.88-1.17, therefore, SLS significantly varies across districts in Gujarat. The variation exists due to high variation in population density, population growth rate, ratio of forest area with gross cropped area, urbanization rate, cropping intensity (ratio of gross cropped area with net sown area), households having toilets, per capita availability of milk production, food-grain yield, ratio of gross irrigated area with gross cropped area, fertilizer consumption/hectare land, per capita district domestic product, agriculture output/hectare land, literacy rate, female literacy rate, households having accessibility to electricity, population having accessibility to safe water, infant mortality rate and birth rate (rural + urban) across districts in Gujarat. Also, estimated correlation coefficients of SLSI with socio-economic variables imply that SLSI is negatively associated with population density $(r=-0.360)$, population growth rate $(r=-0.56)$, urbanization rate $(r=-$ $0.144)$ and infant mortality rate $(r=-0.247)$ (Refer to Table: $\mathrm{C} 1$ in Appendix: C). cropping intensity $(r=0.127)$, households having toilets $(r=0.161)$, food-grain yield $(r=0.308)$, ratio of gross irrigated area with gross copped area $(r=0.136)$, fertilizer consumption/hectare land $(r=0.045)$, per capita district domestic product $(r=0.388)$, agricultural output/hectare land $(r=0.267)$, literacy rate $(r=0.312)$, household having electricity accessibility $(r=$ $0.271)$, population having accessibility of safe water $(r=0.403)$ and birth rate $(r=0.152)$ have a positive association with sustainability livelihood security in Gujarat.

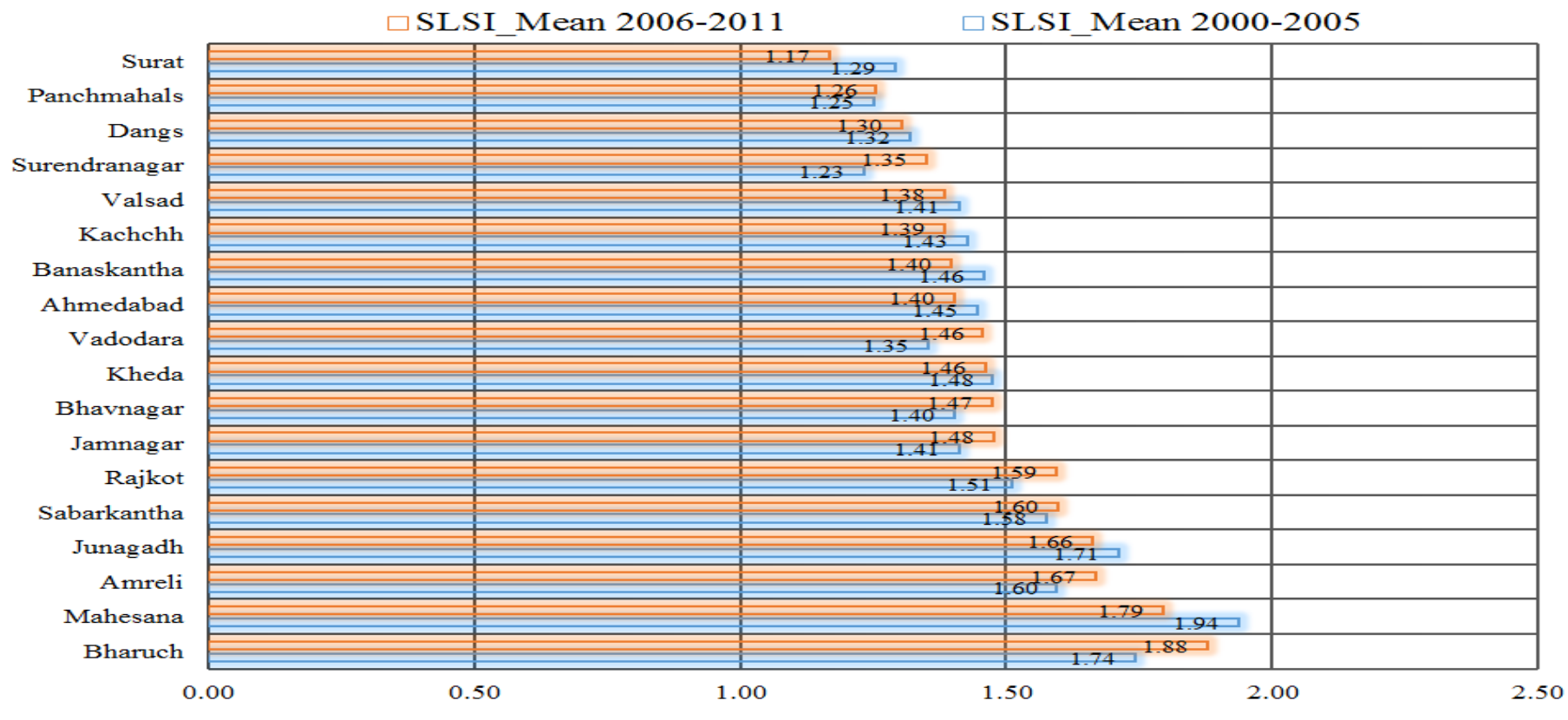

Figure-1. Estimated SLSI across districts in Gujarat 
$\square$ ESI Mean 2006-2011

$\square$ ESI Mean 2000-2005

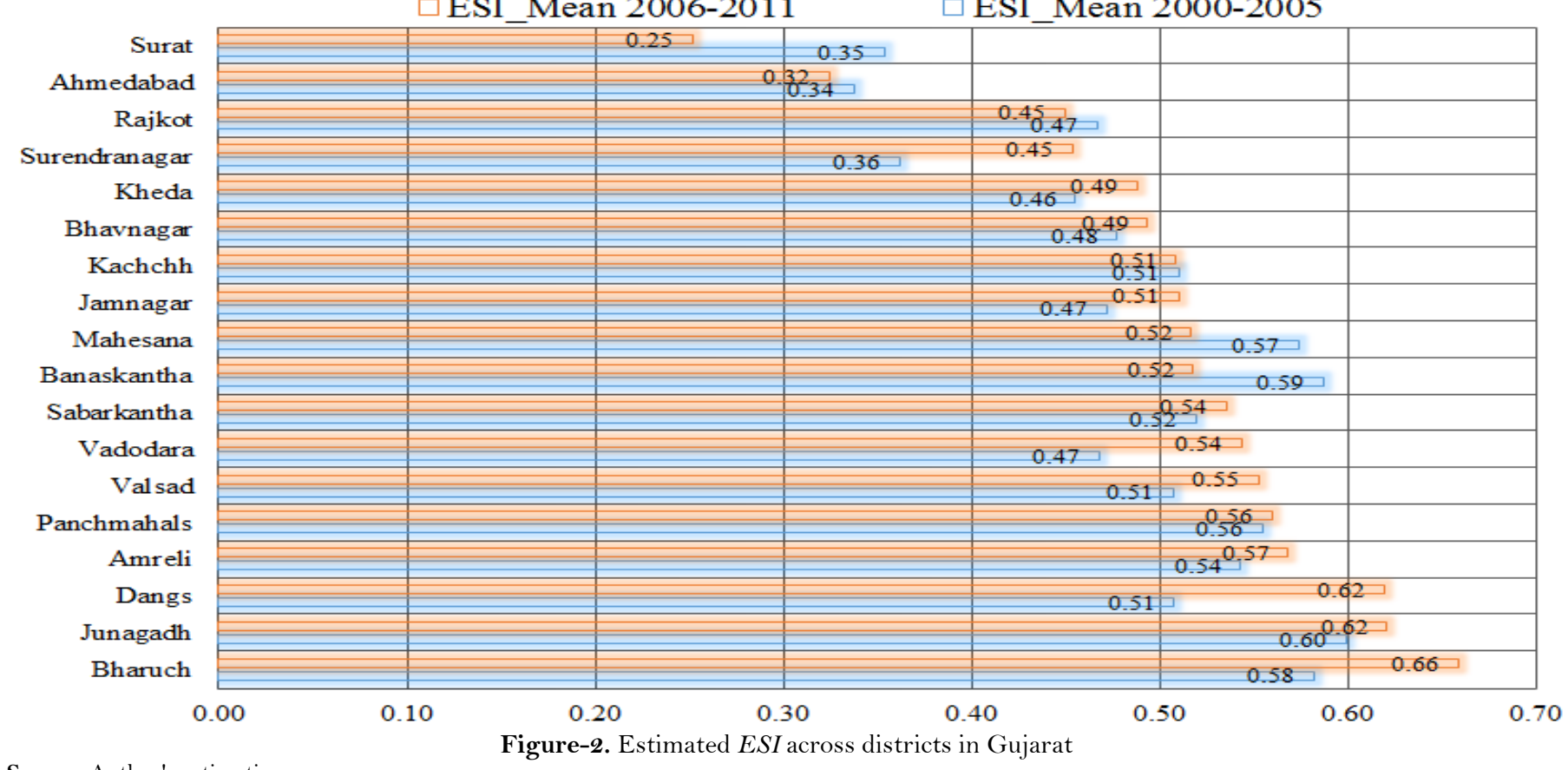

Source: Author's estimation.

Figure: 2 provide the relative position of across districts in estimated ESI during 2000-2011. The estimates demonstrate that Bharuch, Junagadh, Dangs, Amreli, Panchmahal, Valsad, Vadodara, Sabarkantha, Banaskantha, Mahesana, Jamnagar and Kachchh have an ESIs value more than 0.50. Thus, these districts have a better position in ecological security as compared to other districts of Gujarat. Other districts have an ESI s value less than 0.50. Therefore, these districts are in a relatively poor position in the estimated value of ESI. A value of ESI lie between 0.66-0.25, thus it shows that these districts have a significant variation in ecological security due to high variation in population density, population growth rate, ratio of forest area with gross cropped area, urbanization rate, cropping intensity (ratio of gross cropped area with net sown area) and households having toilets across districts in Gujarat. Estimates based on Karl-person correlation coefficients infer that ecological security is negatively correlated with population density $(\mathrm{r}=0.592)$, population growth rate $(r=0.491)$ and urbanization rate $(r=0.620)$. While, ecological security is positively associated with forest area $(r=0.260)$, cropping intensity $(r=0.082)$, per capita availability of milk production $(r=0.288)$ and per capita district domestic product $(r=0.186)$ (Refer to Table: C1 in Appendix: C).

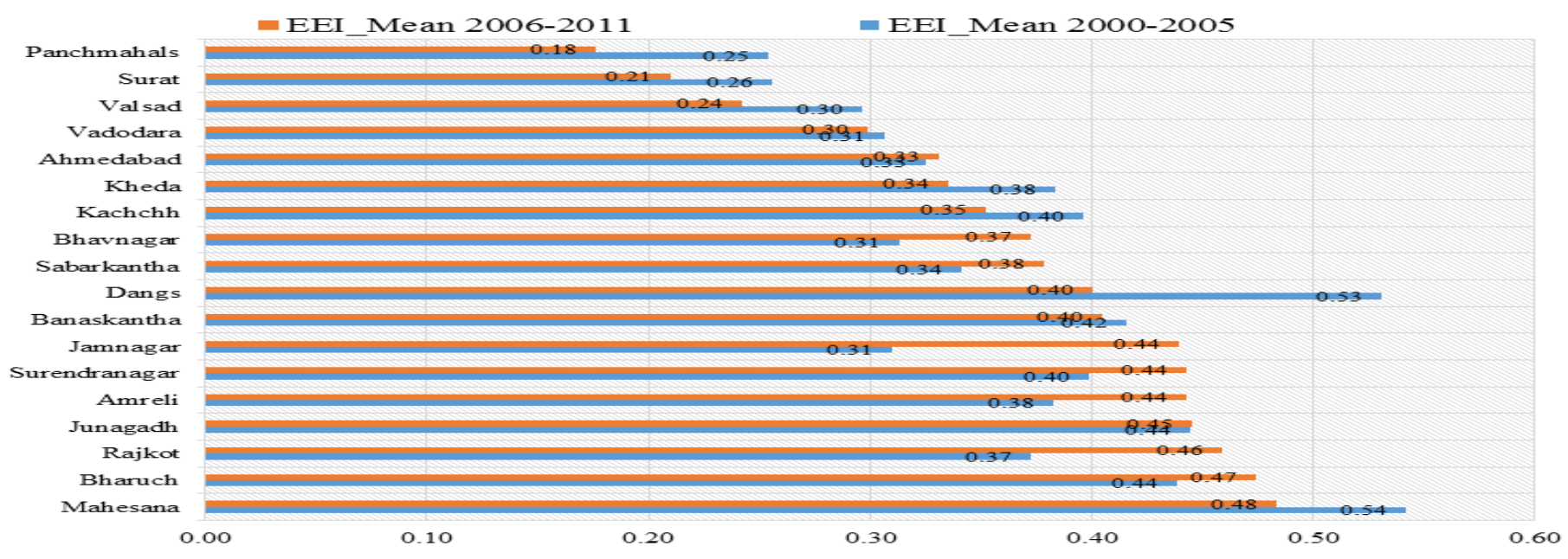

Source: Author's estimation

Figure-3. Estimated EEI across districts in Gujarat

Variation in economic efficiency across districts is measured through economic efficiency index, which is given in Figure: 3. The estimated value of EEI is less than 0.5 across districts, thus these districts are inefficient to maintain economic efficiency. However, the values of EEI are lies between 0.48-0.18 during 2006-2011. Therefore, all districts have a high and significant variation in economic efficiency due to high diversity in per capita availability of milk production, food-grain yield, ratio of a gross irrigated area with gross cropped area, fertilizer consumption/hectare land, per capita district domestic product and agriculture output/hectare land across districts in Gujarat. Estimated correlation coefficients also indicate that economic efficiency is negatively associated with population density $(r=-0.483)$, population growth rate $(r=-0.362)$, urbanization rate $(r=-0.287)$ and infant mortality rate $(r=-0.232)$ (Refer to Table: $\mathrm{C} 1$ in Appendix: $\mathrm{C})$. While, economic efficiency is positively associated with per capita availability of milk production $(r=0.387)$, food-grain yield $(r=0.262)$, ratio of gross irrigated area with gross cropped area $(r=0.499)$, per capita district domestic product $(r=0.499)$ and agricultural output per hectare land $(r=0.362)$.

The variation in social equity across districts is measured through estimation of social equity index (SEI) during 2000-2011, which is given in Figure: 4. The mean value of SEI during 2000-2005 and 2006-2011 shows that these districts have a significant variation in social equity. The estimated values of $S E I$ are observed more than 0.50 during 2006-2001 for Mahesana, Ahmedabad, Bharuch, Surat, Rajkot, Sabarkantha, Amreli, Kheda, Vadodara, 
Bhavnagar, Junagadh, Valsad, Jamnagar, Kachchh, and Panchmahals. Also, the value of SEI lies between 0.79-0.28 for across districts in Gujarat. The variation in SEI exists due to high diversity in literacy rate, female literacy rate, households having electricity accessibility, the population having accessibility to safe water, infant mortality rate and birth rate (rural + urban) across districts in Gujarat. As estimated correlation coefficients of SEI with socioeconomic variables demonstrates that social equity is positively associated with literacy rate $(r=0.767)$, female literacy rate $(r=0.700)$, household having electricity accessibility $(r=0.651)$, population having accessibility of safe water $(r=0.743)$, infant mortality rate $(r=0.196)$ and birth rate $(r=0.085)$, food-grain yield $(r=0.174)$, ratio of gross irrigated area with gross cropped area $(r=0.183)$ and fertilizer consumption per hectare land $(r=0.211)$ (Refer to Table: $\mathrm{C} 1$ in Appendix: C). While social equity is negatively associated with population growth rate $(r=-$ $0.171)$.

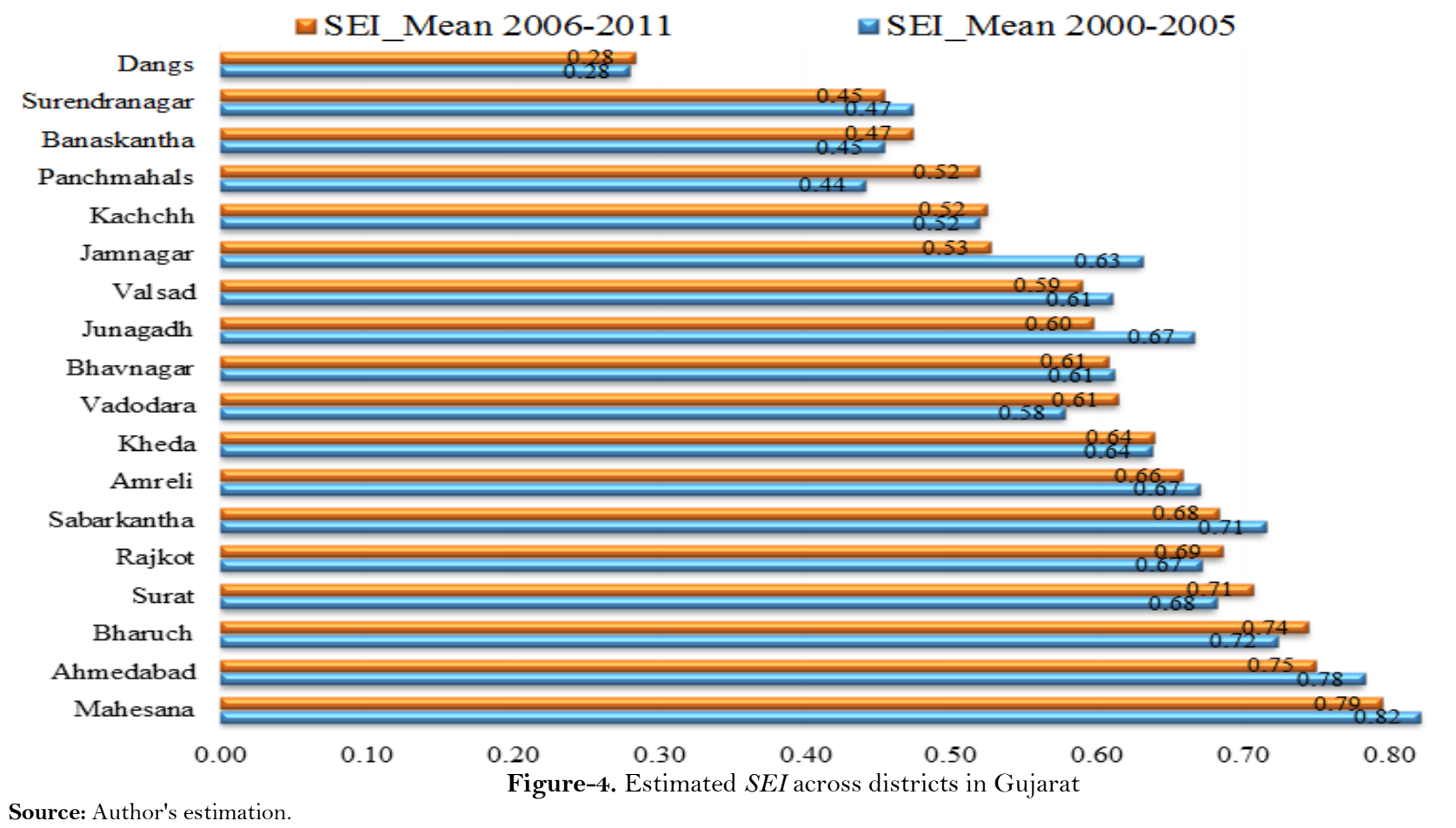

0.90

Source: Author's estimation.

\subsection{Validity and Consistency of Estimated SLSI}

The present study creates district-wise SLSI and its associated indexes i.e. ESI, EEI and SEI using Composite $Z$-score technique. Therefore, it is essential to check the validity and consistency of estimated index to make the unanimity among the researchers and policy makers [25, 34, 36, 44, 47]. It also measures the accuracy and viability of estimated index. In fact, the estimated index can be used for further empirical investigation after validation. The validity of an estimated index can be checked through estimating correlation coefficients among it and its associated index $[25,36,44,47]$. If an estimated index has a positive or negative but statistically significant association with its associated index, then it may be considered as 'good' [25, 36, 44, 47]. In order to check the validity and consistency of estimated SLSI, ESI, EEI and SEI, the Karl Pearson correlation coefficients are estimated among these indicators $[25,36,44,47]$. The correlation coefficients among the SLSI, ESI, EEI and SEI are given in Table: 5. Estimates imply that SLSI is positively associated with ESI, EEI and SEI. Further, it infers that $S L S$ would be improved with increase in ecological security, economic efficiency and social equity in Gujarat. While $E S I$ is negatively associated with $S E I$, thus social equity may be declined as increase in ecological security. Economic efficiency and social equity is also negatively correlated with each other. So, it is a great concern to increase the economic efficiency and social equity in Gujarat.

Table-5. Pearson correlation coefficients among SLSI and its associated indexes

\begin{tabular}{|c|c|c|c|c|}
\hline Parameters & SLSI & ESI & EEI & SEI \\
\hline SLSI & 1 & 0.529 ** & $0.650^{* * *}$ & $0.576^{* * *}$ \\
\hline ESI & $0.529 * *$ & 1 & $0.259^{* *}$ & $-0.188^{*} *$ \\
\hline EEI & $0.650^{* * *}$ & $0.259^{* *}$ & 1 & -0.002 \\
\hline SEI & $0.576^{* * *}$ & $-0.188^{* *}$ & -0.002 & 1 \\
\hline
\end{tabular}

\subsection{Description of Empirical Results}

\subsubsection{Association of $\boldsymbol{S L S I}$ with Climatic Factors}

The association of SLSI with climatic factors are given in Equation (22) and (23). As F-value under Ramsey RESET is statistically insignificant, thus linear regression model produces better results than non-linear regression model. However, results based on non-linear regression model also provide the relationship between SLSI and climatic factors. Regression coefficients based on linear regression model imply that SLS is negatively associated with maximum and minimum temperature, and precipitation during winter, spring, summer and autumn seasons [Note ${ }^{*}{ }^{*} *$ and $*^{*} *$ shows that regression coefficients are statistically significant at $1 \%, 5 \%$ and $10 \%$ significance level in Equation (22)... (29)]. Empirical results also indicate that maximum temperature during spring, summer and autumn seasons show a negative influence on SLS. Minimum temperature during winter and autumn seasons also has a negative association with $S L S$. Besides, regression coefficients of precipitation during 
spring, summer and autumn seasons appeared negative, thus these factors have a negative influence on $S L S$ in Gujarat. The regression coefficient of time trend factor with SLSI under linear and non-linear regression model is found positive. Hence, the technological change would be helpful to increase $S L S$ in Gujarat. Estimates based on non-linear regression model indicate that climatic factors have a non-linear relationship with SLS.

$(S L S I)_{d t}=-10.1103+0.0048(t t f)+0.0971^{*}(\text { amaxtwise })_{d t}-0.0515^{*} *{\text { (amaxtspse })_{d t}}-0.0582$ (amaxtsuse) ${ }_{d t}-0.0042$

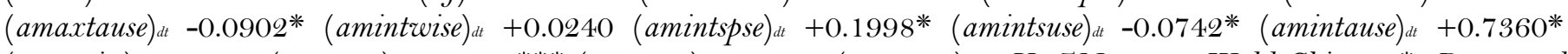

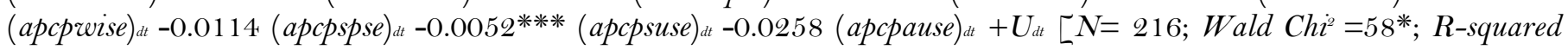
$=0.1985 ;$ Mean $V I F=5.77 ; A I C=-120.4305 ; B I C=-73.1766 ; F-V a l u e($ Ramsey RESET $)=0.35]$

$(S L S I)_{d t}=-3.9216+0.0055(t t f)+0.7385^{* *}(\text { amaxtwise })_{d t}-0.0096^{* * *}\left(\text { amaxtwise } e^{\wedge}\right)_{d t}-0.6937^{* * *}(\text { amaxtspse })_{d t}+0.0084$

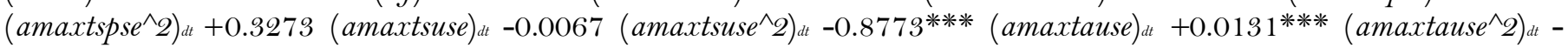

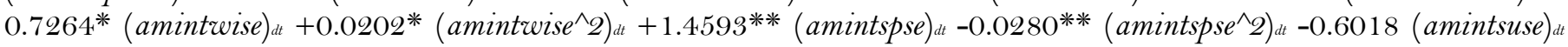
+0.0168 (amintsuse $\left.{ }^{\wedge} 2\right)_{d t}-0.1416$ (amintause) $)_{d t}+0.0012 \quad\left(\text { amintause }^{\wedge} 2\right)_{d t}-0.2353$ (apcpwise)dt $+1.6931(\text { apcpwise } 2)_{d t}$ $+0.0140\left(\text { apcpspse)dt }-0.0029 \text { *** }^{2}\left(\text { apcpspse }{ }^{\wedge} 2\right)_{d t}-0.0126 \text { (apcpsuse }\right)_{d t}+0.0002\left(\text { apcpsuse } e^{\wedge}\right)_{d t}-0.0882(\text { apcpause })_{d t}+0.0117$ $\left(\text { apcpause }^{\wedge} 2\right)_{d t}+\omega_{d t}\left[N=216 ;\right.$ Wald Chi $^{2}=84.05^{*} ;$ R-squared $=0.2889 ;$ Mean VIF $=2149.81 ;$ AIC $=-122.2791 ;$ BIC $=-$ $34.5219 ;$ F-Value (Ramsey RESET) $\left.=2.23^{* * *}\right]$

\subsubsection{Association of $\boldsymbol{E S I}$ with Climatic Factors}

The empirical relationship between estimated ESI with climatic factors is given in Equation (24) and (25). The regression coefficients of explanatory variables are estimated through linear and non-linear regression models. As the $F$-value under Ramsay RESET test is found statistically insignificant for both the models, thus these models produce better and viable results. Estimates indicate that maximum temperature during spring and summer seasons have a negative influence on ecological security. Also, regression coefficients of minimum temperature during winter and summer seasons with ESI is found negative. Therefore, ecological security is negatively impacted due to change in minimum temperature in aforesaid seasons. Precipitation during spring and summer seasons also brings negative implications on ecological security. As regression coefficients of the original term of climatic factors and square term of climatic factors with ESI have an opposite sign. So, climatic factors have a nonlinear relationship with ecological security. It also found that climatic factors have U-shape and Hilly-shape relationship with ecological security.

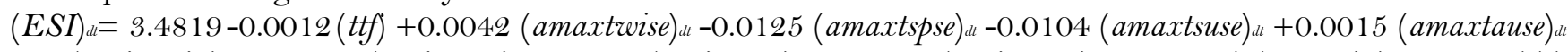

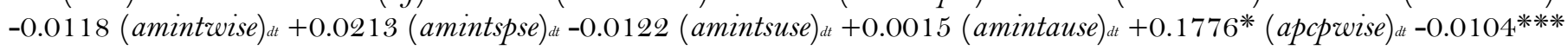

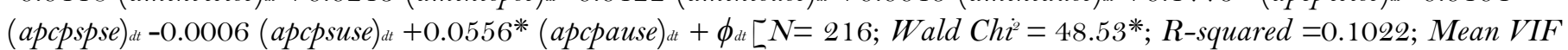
$=5.77 ; A I C=-330.0421 ; B I C=-377.296 ; F-\operatorname{Value}($ Ramsey RESET $)=0.21]$

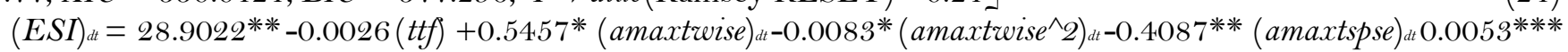

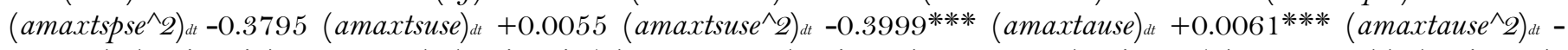
0.2754* (amintwise $)_{d t}+0.0083^{*}$ (amintwise $\left.^{\wedge} 2\right)_{d t}+0.2342$ (amintspse) $)_{d t}-0.0044$ (amintspse $\left.{ }^{\wedge}\right)_{d t}-1.0333^{*} *$ (amintsuse $_{d t}$ $+0.0212^{* *}\left(\text { amintsuse }^{\wedge} 2\right)_{d t}+0.0589$ (amintause) $_{d t}-0.0018$ (amintause $\left.^{\wedge} 2\right)_{d t}+0.2123$ (apcpwise) at $-0.1447\left(\text { apcpwise }{ }^{\wedge} 2\right)_{d t}-$ $0.0171^{* * * *}(\text { apcpspse })_{d t}+0.0009(\text { apcpspse } 2)_{d t}-0.0095^{* *}(\text { apcpsuse })_{d t}+0.0003^{* * *}($ apcpsuse 2$\left.)\right)_{d t}+0.1152^{* *}(\text { apcpause })_{d t}-$ $0.0400\left(\text { apcpause }^{\wedge} 2\right)_{d t}+\varepsilon_{d t}\left[N=216 ;\right.$ Wald Chi $^{2}=95.81^{*} ;$ R-squared $=0.1973 ;$ Mean VIF $=2149.81 ;$ AIC $=-377.4848$; $B I C=-289.7276 ;$ F-Value $($ Ramsey RESET $)=1.70]$

\subsubsection{Association of $E E I$ with Climatic Factors}

The empirical association between economic efficiency index (EEI) and climatic factors are estimated through linear and non-linear regression models. Regression coefficients of climatic factors with EEI are given in Equation (26) and (27). F-Value under Ramsay RESET test is found statistically insignificant for the linear regression model, therefore this model produces better results than non-linear regression model. The regression coefficient of time trend factor with EEI is observed positive and statistically significant. It implies that adoption of technology in production activities would be helpful to increase the economic efficiency of resources. Thus, it is suggested to apply advanced technology in production activities in those districts and rural areas which are using lower technologies in production activities. Regression coefficients of maximum temperature during spring, summer and autumn seasons are found negative, thus it shows that maximum temperature during aforesaid periods would be caused to decrease economic efficiency. Minimum temperature during winter, spring and autumn seasons also have a negative influence on economic efficiency. Economic efficiency is also negatively influenced due to variability in precipitation during summer and autumn seasons. The estimates can be consistent with those studies which estimate climate change impact on the individual indicator of economic efficiency i.e. per capita availability of milk production, food-grain yield [25] ratio of gross irrigated are with a gross cropped area, per capita district domestic product, agricultural output/Ha land [50]. Estimates based on non-linear regression model provide crucial evidence that climatic factors have a non-linear relationship with economic efficiency in Gujarat.

$(E E I)_{d t}=-13.0881^{* * *}+0.0074^{* * * *}(t t f)+0.0355^{* *}(\text { amaxtwise })_{d t}-0.0372^{*}(\text { amaxtspse })_{d t}-0.0171$ (amaxtsuse $)_{d t}-0.0122$

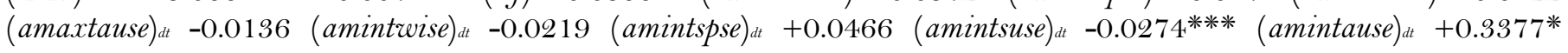

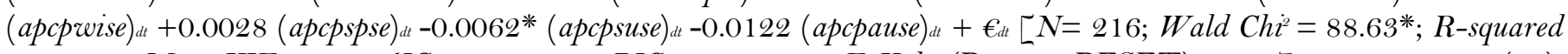
$=0.2454 ;$ Mean $V I F=5.77 ; A I C=-418.3421 ; B I C=-371.0882 ; F-$ Value $($ Ramsey RESET $)=0.21]$

$(E E I)_{d t}=9.8363+0.0052(t t f)+0.1606$ (amaxtwise) $d t-0.0022(\text { amaxtwise } 2)_{d t}+0.3257^{* * * *}(\text { amaxtspse })_{d t}-0.0047^{* * * *}$ $\left(\text { amaxtspse } e^{\wedge}\right)_{d t}-0.0047^{* * *}{ }^{*}(\text { amaxtsuse })_{d t}+0.0137^{*} *\left(\text { amaxtsuse } e^{\wedge}\right)_{d t}+0.0878(\text { amaxtause })_{d t}-0.0016\left(\text { amaxtause } e^{\wedge}\right)_{d t}-$ 0.0619 (amintwise) $d t_{d t}+0.0018$ (amintwise $\left.{ }^{\wedge} \mathcal{2}\right)_{d t}+0.2005$ (amintspse) $)_{d t}-0.0044 \quad$ (amintspse $\left.{ }^{\wedge} 2\right)_{d t}-1.4442^{*} \quad($ amintsuse) $d t$ $+0.0297^{*}\left(\text { amintsuse }^{\wedge} 2\right)_{d t}+0.0190$ (amintause $)_{d t}-0.0008\left(\text { amintause }^{\wedge} 2\right)_{d t}-0.0256$ (apcpwise) $)_{d t}+0.6172(\text { apcpwise } 2)_{d t}$ $+0.0262^{* *}\left(\text { apcpspse)dt }-0.0026^{* *}(\text { apcpspse })^{\wedge}\right)_{d t}+0.0015$ (apcpsuse) $)_{d t}-0.0003 * * * \quad\left(\text { apcpsuse }{ }^{\wedge} 2\right)_{d t}-0.0352(\text { apcpause })_{d t}$ $+0.0126\left(\text { apcpause }^{\wedge} 2\right)_{d t}+\mu_{d t}\left[N=216 ;\right.$ Wald Chi $^{2}=193.19^{*} ;$ R-squared $=0.3375 ;$ Mean VIF $=2149.81 ;$ AIC $=-422.4792$; $B I C=-334.722 ;$ F-Value $\left(\right.$ Ramsey RESET) $\left.=2.970^{* *}\right]$ 


\subsubsection{Association of $S E I$ with Climatic Factors}

The association of climatic factors with social equity index $(S E I)$ is estimated through linear and non-linear regression models. The regression coefficient of climatic factors with SEI is presented in Equation (28) and (29). Regression coefficients of maximum temperature during spring and summer seasons has a negative and statistically significant influence on SEI. It means that social equity is negatively impacted due to variability in climatic factors. The influence of minimum temperature during winter and autumn seasons on SEI is also found negative. It infers that minimum temperature during the aforesaid periods have a negative impact on social equity. Regression coefficients of precipitation during spring and autumn seasons with SEI are appeared negative. Thus, social equity also negatively influenced due to change in precipitation during spring and autumn seasons. Estimates based on non-linear regression model indicates that climatic factors have a non-linear relationship. Also, climatic factors have a U-shaped and hilly-shaped relation with social equity. Since, the social equity index includes several factors i.e. literacy rate, female literacy rate, households having electricity accessibility, population having accessibility to safe water, infant mortality rate and birth rate.

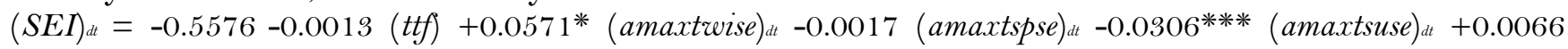

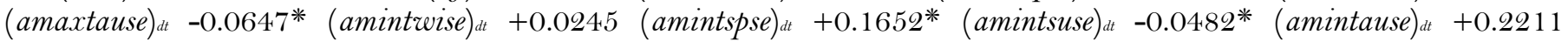

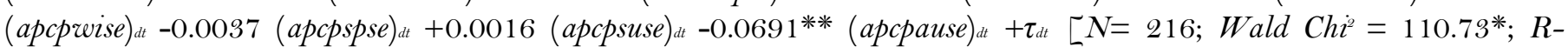
squared $=0.3201 ;$ Mean VIF $=5.77 ; A I C=-326.1622 ; B I C=-278.9083 ; F-$ Value $($ Ramsey RESET $)=5.12]$

$(S E I)_{d t}=-42.6509^{*}+0.0029(t t f)+0.0302\left(\right.$ amaxtwise $_{d t}+0.0009\left(\text { amaxtwise }^{\wedge} 2\right)_{d t}-0.6089^{*} *\left(\right.$ amaxtspse $_{d t}+0.0077^{* *}$

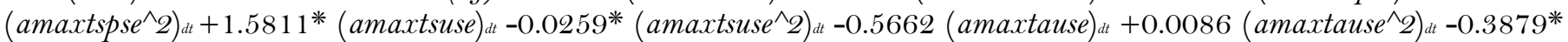
$(\text { amintwise })_{d t}+0.0101^{* *}\left(\text { amintwise }{ }^{\wedge} 2\right)_{d t}+1.0255^{* * *}(\text { amintspse })_{d t}-0.0192^{*}(\text { amintspse } 2)_{d t}+1.8689^{*}$ (amintsuse $)_{d t}-$ 0.0341* (amintsuse $\left.{ }^{\wedge}\right)_{d t}-0.2185^{*} *$ (amintause $_{d t}+0.0039$ (amintause $\left.^{\wedge} 2\right)_{d t}-0.4217$ (apcpwise $)_{d t}+1.2210^{*} * *{ }^{*}\left(\text { apcprise } e^{\wedge} 2\right)_{d t}$ $+0.0049(\text { apcpspse })_{d t}-0.0012\left(\text { apcpspse }{ }^{\wedge} 2\right)_{d t}-0.0046$ (apcpsuse $)_{d t}+0.0001 \quad\left(\text { apcpsuse }{ }^{\wedge} 2\right)_{d t}-0.1684^{*}(\text { apcpause })_{d t}+0.0393$

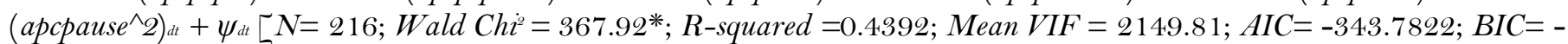
256.0249; F-Value (Ramsey RESET) $=2.23 * * *$ ]

\section{Conclusion and Policy Suggestions}

The main aim of this study is to estimate the district-wise sustainable livelihood security index (SLSI) in Gujarat using Composite Z-score technique during 2000-2011. For this, the study creates ecological sustainability index $(E S I)$, economic efficiency index (EEI) and social equity index $(S E I)$. SLSI is measured as an integrated index of ESI, EEI and SEI for aforesaid period. Eighteen different variables are compiled as a single number to estimate the district-wise SLSI. Accordingly, it used linear and non-linear regression models to examine the influence of climatic factors (i.e., maximum temperature, minimum temperature and precipitation) in winter, spring, summer and autumn seasons on SLSI, ESI, EEI and SEI.

Descriptive results indicate that there is existence high variation in sustainable livelihood security, ecological security, economic efficiency and social equity across districts in Gujarat. It is also observed that variation in SLSI, $E S I, E E I$ and SEI exists due to the significant diversity of socio-economic and health related factors (i.e. population density, population growth rate, ratio of forest area with gross cropped area, urbanization rate, cropping intensity (ratio of gross cropped area with net sown area), households having toilets, per capita availability of milk production, food-grain yield, ratio of gross irrigated area with gross cropped area, fertilizer consumption/hectare land, per capita district domestic product, agriculture output/hectare land, literacy rate, female literacy rate, households having electricity accessibility, population having accessibility to safe water, infant mortality rate and birth rate) across districts in Gujarat. Moreover, the estimated correlation coefficients imply that SLSI is positively and significantly associated with ESI, EEI and SEI. So, it shows that SLS would be improved as the increase in ecological security, economic efficiency and social equity in Gujarat. Empirical results based on linear and nonlinear regression models show that sustainable livelihood security, ecological security, economic efficiency and social equity are negatively associated with climatic factors during winter, spring, summer and autumn seasons. Estimates also demonstrate that sustainable livelihood security, ecological security, economic efficiency and social equity have a non-linear relationship with climatic factors. Here, it can be concluded that SLS would be in alarming position due to climate change in Gujarat.

As SLSI is negatively associated with population density, population growth rate, urbanization rate and infant mortality rate. Thus national policy maker need to adopt a policy which must reduce the negative implications of these factors on $S L S$ in Gujarat. cropping intensity, households having toilets, food-grain yield, ratio of gross irrigated area with gross copped area, fertilizer consumption/hectare land, per capita district domestic product, agricultural output/hectare land, literacy rate, household having electricity accessibility, population having accessibility of safe water and birth rate have a positive association with $S L S$ in Gujarat. Thus, these factors may be considered for further policy formulation. Furthermore, it is essential to control population density, population growth rate and urbanization rate in order to maintain ecological security. For this, protection of forest area, and to increase cropping intensity, per capita availability of milk production and per capita district domestic product would be helpful to sustain ecological security. It is also suggested to maintain the pace of population density, population growth and urbanization, infant mortality rate to increase economic efficiency in Gujarat. For this, increase in per capita availability of milk production, food-grain yield, ratio of gross irrigated area with gross cropped area, per capita district domestic product and agricultural output/hectare land would be imperative to improve economic efficiency in this state. Social equity would be improved as increase in literacy rate, female literacy rate, household having electricity accessibility, population having accessibility of safe water and birth rate, food-grain yield, ratio of the gross irrigated area with gross cropped area and fertilizer consumption/hectare land.

Empirical results also suggested that there is indispensable to implement the effective management policies to preserve the natural resource to maintain $S L S$ in Gujarat [1]. Forest area play a significant role to maintain the ecological security, consequently forest area may be useful to conserve the other ecosystem services [31, 35, 44]. It is also desirable to apply labour-intensive and small-scale farming to contribute more to productivity and social prosperity in Gujarat. Then, it would be useful to increase SLS in Gujarat. There is essential to increase micro- 
irrigation facility, efficient water management policy, and adoption of advanced technologies in cultivation to maintain the $S L S$ in Gujarat [26].

\section{References}

[1] A. Habibah, J. Hanzah, and I. Mushrifath, "Sustainable livelihood of the community in Tasik Chini Biosphere reserve: The local practices," Journal of Sustainable Development, vol. 3, pp. 184-196, 2010. View at Google Scholar | View at Publisher

[2] S. Morse, N. McNamara, and M. Acholo, "Sustainable livelihood approach: A critical analysis of theory and practice," Geographical Paper No. 189, The University of Reading, 2009.

[3] C. K. Ajaero, "Mapping the livelihood status of migrant-sending rural households in Southeastern Nigeria," IOSR Journal of Humanities and Social Science, vol. 19, pp. 128-136, 2014.

[4] K. Ponnusamy and J. Gupta, "Fisheries based farming system for sustainable livelihood of coastal farmers," Indian Journal of Fisheries, vol. 54, pp. 327-331, 2007. View at Google Scholar

[5] P. K. Singh and B. N. Hiremath, "Sustainable livelihood security index in a developing country: A tool for developing planning," Ecological Indicators, vol. 10, pp. 442-451, 2010. View at Google Scholar $\mid$ View at Publisher

[6] S. Akter and S. Rahman, "Investing livelihood security in poor settlements in Bangladesh," presented at the 86th Annual Conference of the Agricultural Economics Society, University of Warwick, United Kingdom, 16-18 April, $2012,2012$.

[7] R. Kamaruddin and S. Samsudin, "The sustainable livelihoods index: A tool to assess the ability and preparedness of the rural poor in receiving entrepreneurial project," Journal of Social Economic Research, vol. 1, pp. 108-117, 2014. [8] H. Sajjad, I. Nasreen, and S. A. Ansari, "Assessing spatiotemporal variation in agricultural sustainability using sustainable
livelihood security index: Empirical illustration from Vaishali District of Bihar, India," Agroecology and Sustainable Food Systems, vol. 38, pp. 46-68, 2014. View at Google Scholar | View at Publisher

[9] R. Attfield, J. Hattingh, and M. Matshabaphala, "Sustainable development, sustainable livelihoods and land reforms in South Africa: A conceptual and ethical inquiry," Third World Quarterly, vol. 25, pp. 405-42 1, 2004. View at Google Scholar $\mid$ View at Publisher

[10] L. Connolly-Boutin and B. Smit, "Climate change, food security, and livelihoods in Sub-Saharan Africa," Regional Environmental Change, vol. 16, pp. 385-399, 2016. View at Google Scholar $\mid$ View at Publisher

[11] M. Lindenberg, "Measuring household livelihood security at the family and community level in the developing world," World Development, vol. 30, pp. 301-318, 2002. View at Google Scholar | View at Publisher

[12] P. S. Patra, G. Mula, B. Paramanik, S. C. Sarkar, and A. Srakar, "Assessing the economic and social consequences of sustainability of rural livelihood in Eastern India," African Journal of Agricultural Research, vol. 7, pp. 4660-4668, 2012. View at Google Scholar

[13] C. Turton, "The sustainable livelihoods approach and programme development in Cambodia," Overseas Development Institute, Portland House, London, UK, Working Paper No.130, 2000.

[14] A. B. Bhuiyan, "Microcredit and sustainable livelihood: An empirical study of Islamic and conventional credit on the development of human capital of the Borrowers in Bangladesh," Journal of Economic Cooperation and Development, vol. 34, pp. 101-128, 2013. View at Google Scholar

[15] Madhuri, H. R. Tewari, and P. K. Bhowmick, "Livelihood vulnerability index analysis: An approach to study vulnerability in the context of Bihar," Journal of Disaster Risk Studies, vol. 6, pp. 1-13, 2014. View at Google Scholar | View at Publisher

[16] L. Krantz, The sustainable livelihood approach to poverty reduction: An introduction. Stockholm, Sweden: Swedish International Development Cooperation Agency, Division for Policy and Socio-Economic Analysis, Swedish International Development Cooperation Agency, 2001.

[17] C. Böhringer and P. Jochem, "Measuring the immeasurable: A survey of sustainability indices," ZEW Discussion Paper, No. O6-O73, Centre for European Economic Research 2006.

[18] D. B. Hiremath and R. L. Shiyani, "Analysis of vulnerability indices in various Agro-climatic Zones of Gujarat," Indian Journal of Agricultural Economics, vol. 68, pp. 122-137, 2013. View at Google Scholar

[19] A. Ighodalo, "Poverty and sustainable socio-economic development in Africa: The Nigeria experience," European Scientific Journal, vol. 8, pp. 51-65, 2012. View at Google Scholar

[20] J. Duasa and R. Afroz, "Modeling environment performance and economic development," International Journal of Trade, Economics and Finance, vol. 4, pp. 384-387, 2013. View at Google Scholar $\mid$ View at Publisher

[21] A. G. Awan, "Relationship between environment and sustainable development: A theoretical approach to environmental problems," International Journal of Asian Social Science, vol. 3, pp. 741-761, 2013. View at Google Scholar

[22] I. A. Tampakoudis, D. Fylantzopoulou, and N. Konstantina, "Examining the linkages between GDP growth and sustainable development in Eurozone," EAST-WEST Journal of Economic and Business, vol. 17, pp. 15-34, 2014.

[23] A. Kumar, P. Sharma, and S. K. Ambrammal, "Climatic effects on food grain productivity in India: A crop-wise analysis," Journal of Studies in Dynamics and Change, vol. 1, pp. 38-48, 2014. View at Google Scholar

[24] P. S. Birthal, M. T. Khan, D. Negi, and S. Agarwal, "Impact of climate change on yields of major food grain crops in India: Implications of food security," Agricultural Economics Research Review, vol. 27, pp. 145-155, 2014. View at Google Scholar | View at Publisher

[25] A. Kumar, M. M. Ahmad, and P. Sharma, "Influence of climatic and non-climatic factors on sustainable food security in India: A statistical investigation," International Journal of Sustainable Agricultural Management and Informatics, vol. 3, pp. 1-30, 2017. View at Google Scholar | View at Publisher

[26] M. G. Ghabru, G. Devi, and R. Singh, "Estimating agricultural sustainability in Gujarat using sustainable livelihood security index," Agricultural Economics Research Review, vol. 30, pp. 125-131, 2017. View at Google Scholar | View at Publisher

[27] S. Parwez, "A comparative study of Gujarat and Kerala development experiences," International Journal of Rural Management, vol. 12, pp. 104-124, 2016. View at Google Scholar | View at Publisher

[28] A. J. Samimi, A. Kashefi, P. Salatin, and M. Lashkarizadeh, "Environmental performance and HDI: Evidence from countries around the world," Middle East Journal of Scientific Research, vol. 10, pp. 294-301, 201 1. View at Google Scholar

[29] S. Mukherjee and D. Chakraborty, "Is environmental sustainability influenced by socioeconomic and sociopolitical factors? Crosscountry empirical evidence," Sustainable Development, vol. 21, pp. 353- 371, 2013. View at Google Scholar $\mid$ View at Publisher

[30] P. Singh and S. Keshari, "Development of human development index at district level for EAG states," Statistics and Applications, vol. 14, pp. 43-61, 2016. View at Google Scholar

[31] R. Dash, Environmental sustainability index for Indian states 2011: Informing environmental action. Chennai: Centre for Development Finance, Institute for Financial Management and Research, 2011.

[32] I. Gallego-Álvarez, M. P. Vicente-Galindo, M. P. Galindo-Villardón, and M. Rodríguez-Rosa, "Environmental performance in countries worldwide: Determinants factors and multivariate analysis," Sustainability, vol. 6, pp. 7807-7832, 2014. View at Google Scholar | View at Publisher

[33] D. Lee, S. Kang, and J. Shin, "Determinants of pro-environmental consumption: Multicountry comparison based upon big data search," Sustainability, vol. 9, pp. 183, 2017. View at Google Scholar | View at Publisher

[34] A. K. Singh, M. M. Ahmad, and P. Sharma, "Implications of socioeconomic factors on food security in selected economies: An empirical assessment," Journal of Global Economics, Management and Business Research, vol. 8, pp. 103-115, 2017 a.

[35] A. K. Singh, K. G. S. Narayanan, and P. Sharma, "Influence of climate variability on sugarcane farming in India: An empirical research. In Nandan Nawn and Joy Elamon (Eds)," in Proceedings of the 9th Biennial Conference 2017 of the Indian Society for Ecological Economics (INSEE) on Sustainability, Institutions, Incentives: Voices, Policies and Commitments, Organized by Kerala Institute of Local Administration, Thrissur [November 8-10, 2017], Indian Society for Ecological Economics, New Delhi, 2018.

[36] A. Tripathi, "Socio-economic backwardness and vulnerability to climate change: Evidence from Uttar Pradesh State in India," Journal of Environmental Planning and Management, vol. 60, pp. 328-350, 2016. View at Google Scholar | View at Publisher

[37] M. Chinnadurai, T. Nalini, and B. Swaminathan, "Livelihood security status in the dryland areas of Bellary district, Karnataka," International Journal of Science and Nature, vol. 3, pp. 857-862, 2012. View at Google Scholar 
[38] D. A. Adu, J. K. M. Kuwornu, H. Anim-Somuah, and N. Sasaki, "Application of livelihood vulnerability index in assessing smallholder maize farming households' vulnerability to climate change in Brong-Ahafo region of Ghana," Kasetsart Journal of Social Sciences, vol. 2, pp. 1-1 1, 2017. View at Google Scholar $\mid$ View at Publisher

[39] P. Sharma and A. K. Singh, "Association of state-wise food security index with climatic factors in India: Evidence from state-wise panel data," Journal of Global Agriculture and Ecology, vol. 6, pp. 196-205, 2017.

[40] A. K. Singh, Climate change and productivity of food-grain and cash crops in India. Mauritius: LAP LAMBERT Academic Publishing, 2017.

[41] A. K. Singh, S. R. Acharya, and P. Chavda, "Implications of intellectual property rights and socio-economic factors on growth of manufacturing sector in selected cross economies: An empirical assessment. In Sasi Misra, Sunil Shukla and Ganapathi Batthini (Eds)," in Proceedings of the Twelfth Biennial Conference on Entrepreneurship Organized by EDII Ahmedabad [Feb 22-24, 2017]. New Delhi: Bookwell Publishing House, 2017.

[42] F. Booysen, "An overview and evaluation of composite indices of development," Social Indicators Research, vol. 59, pp. 115-151, 2002. View at Google Scholar

[43] S. Maiti, S. K. Jha, S. Garai, A. Nag, R. Chakravarty, K. S. Kadian, B. S. Chandel, K. K. Datta, and R. C. Upadhyay, "Assessment of social vulnerability to climate change in the Eastern coast of India," Climate Change, vol. 131, pp. 287-306, 2015. View at Google Scholar $\mid$ View at Publisher

[44] A. Kumar, M. M. Ahmad, and P. Sharma, "Carbon emission and global food security: A cross country analysis," PENCIL Publication of Agricultural Sciences, vol. 2, pp. 7-24, 2015. View at Google Scholar

[45] A. K. Singh and P. Sharma, "Implications of climatic and non-climatic variables on food security in developing economies: A conceptual review," MOJ Food Processing \& Technology, vol. 6, pp. 1-12, 2018. View at Google Scholar | View at Publisher

[46] A. B. Demeke, A. Keil, and M. Zeller, "Using panel data to estimate the effect of rainfall shock on smallholders food security and vulnerability in rural Ethiopia," Climate Change, vol. 108, pp. 185-206, 2011 . View at Google Scholar | View at Publisher

[47] A. Kumar and P. Sharma, "Impact of climate variation on agricultural productivity and food security in rural India," Economics Discussion Papers, No. 2013-43, Kiel Institute for the World Economy Germany, 2013.

[48] L. Ye, W. Xiong, Z. Li, P. Yang, W. Wu, G. Yang, Y. Fu, J. Zou, Z. Chen, E. V. Ranst, and H. Tang, "Climate change impact on China food security in 2050," Agronomy for Sustainable Development, vol. 33, pp. 363-374, 2013. View at Google Scholar

[49] M. Belloumi, "Investigating the linkage between climate variables and food security in ESA countries," AGRODEP Working Paper No. 0004, 2014 .

[50] A. Kumar, P. Sharma, and S. Joshi, "Assessing the impacts of climate change on land productivity in Indian crop agriculture: An evidence from panel data analysis," Journal of Agricultural Science and Technology, vol. 18, pp. 1-13, 2016. View at Google Scholar

\section{Appendix: A}

Table-A1. Estimated district-wise sustainable livelihood security index (SLSI) during 2000-2011

\begin{tabular}{|c|c|c|c|c|c|c|c|c|c|c|c|c|}
\hline District & 2000 & 2001 & 2002 & 2003 & 2004 & 2005 & 2006 & 2007 & 2008 & 2009 & 2010 & 2011 \\
\hline Ahmedabad & 1.515 & 1.520 & 1.373 & 1.379 & 1.447 & 1.436 & 1.501 & 1.374 & 1.337 & 1.386 & 1.463 & 1.362 \\
\hline Amreli & .552 & 1.518 & 1.588 & 1.608 & 1.707 & 1.601 & 1.685 & 1.655 & 1.703 & 1.599 & 1.702 & 1.674 \\
\hline Banaskantha & 1.449 & 1.490 & 1.390 & 1.487 & 1.535 & 1.393 & 1.295 & 1.389 & 1.356 & 1.427 & 1.502 & 1.405 \\
\hline Bharuch & 1.688 & 1.599 & 1.770 & 1.809 & 1.766 & 1.829 & 2.019 & 1.762 & 1.886 & 1.800 & 1.913 & 1.885 \\
\hline Bhavnagar & 1.408 & 1.324 & 1.326 & 1.452 & 1.428 & 1.475 & 1.470 & 1.430 & 1.460 & 1.469 & 1.501 & 1.509 \\
\hline Dangs & 1.380 & 1.351 & 1.273 & 1.311 & 1.182 & 1.415 & 1.162 & 1.321 & 1.288 & 1.335 & 1.354 & 1.356 \\
\hline Jamnagar & 1.367 & 1.335 & 1.356 & 1.371 & 1.598 & 1.445 & 1.505 & 1.466 & 1.463 & 1.475 & 1.551 & 1.398 \\
\hline Junagadh & 1.650 & 1.677 & 1.692 & 1.679 & 1.853 & 1.714 & 1.633 & 1.648 & 1.617 & 1.705 & 1.770 & 1.607 \\
\hline Kachchh & 1.528 & 1.416 & 1.354 & 1.388 & 1.396 & 1.476 & 1.466 & 1.346 & 1.365 & 1.360 & 1.430 & 1.344 \\
\hline Kheda & 1.500 & 1.551 & 1.447 & 1.515 & 1.453 & 1.387 & 1.375 & 1.358 & 1.380 & 1.516 & 1.607 & 1.533 \\
\hline Mahesana & 1.836 & 2.084 & 1.969 & 1.953 & 1.920 & 1.857 & 1.754 & 1.764 & 1.742 & 1.817 & 1.896 & 1.795 \\
\hline Panchmahals & 1.322 & 1.256 & 1.308 & 1.263 & 1.198 & 1.155 & 1.208 & 1.190 & 1.213 & 1.245 & 1.352 & 1.327 \\
\hline Rajkot & 1.463 & 1.367 & 1.411 & 1.415 & 1.692 & 1.718 & 1.724 & 1.580 & 1.594 & 1.503 & 1.631 & 1.531 \\
\hline Sabarkantha & 1.638 & 1.579 & 1.518 & 1.491 & 1.643 & 1.585 & 1.457 & 1.514 & 1.594 & 1.652 & 1.744 & 1.627 \\
\hline Surat & 1.478 & 1.255 & 1.272 & 1.212 & 1.233 & 1.294 & 1.238 & 1.116 & 1.232 & 1.131 & 1.159 & 1.134 \\
\hline Surendranagar & 1.211 & 1.179 & 1.183 & 1.159 & 1.298 & 1.375 & 1.346 & 1.271 & 1.315 & 1.314 & 1.446 & 1.412 \\
\hline Vadodara & 1.396 & 1.293 & 1.306 & 1.375 & 1.397 & 1.348 & 1.398 & 1.293 & 1.477 & 1.508 & 1.578 & 1.487 \\
\hline Valsad & 1.579 & 1.471 & 1.382 & 1.394 & 1.349 & 1.305 & 1.465 & 1.324 & 1.359 & 1.378 & 1.300 & 1.481 \\
\hline
\end{tabular}

Source: Author's estimation.

Table-A2. Estimated district-wise ecological security index (ESI) during 2000-2011

\begin{tabular}{|c|c|c|c|c|c|c|c|c|c|c|c|c|}
\hline District & 2000 & 2001 & 2002 & 2003 & 2004 & 2005 & 2006 & 2007 & 2008 & 2009 & 2010 & 2011 \\
\hline Ahmedabad & 435 & 0.404 & .297 & 0.311 & 0.301 & 0.277 & 0.282 & 0.296 & 0.296 & 0.360 & 0.363 & 0.350 \\
\hline Amreli & 0.631 & 0.591 & 0.493 & 0.510 & 0.527 & 0.508 & 0.570 & 0.529 & 0.561 & 0.581 & 0.589 & 0.581 \\
\hline Banaskantha & 0.623 & 0.622 & 0.563 & 0.621 & 0.612 & 0.485 & 0.445 & 0.498 & 0.481 & 0.588 & 0.569 & 0.528 \\
\hline Bharuch & 0.660 & 0.517 & 0.588 & 0.579 & 0.586 & 0.565 & 0.748 & 0.571 & 0.698 & 0.644 & 0.656 & 0.638 \\
\hline Bhavnagar & 0.529 & 0.512 & 0.441 & 0.480 & 0.475 & 0.428 & 0.449 & 0.457 & 0.470 & 0.534 & 0.536 & 0.516 \\
\hline Dangs & 0.554 & 0.499 & 0.436 & 0.452 & 0.467 & 0.641 & 0.462 & 0.663 & 0.600 & 0.645 & 0.675 & 0.674 \\
\hline Jamnagar & 0.519 & 0.481 & 0.438 & 0.449 & 0.496 & 0.449 & 0.482 & 0.477 & 0.503 & 0.538 & 0.540 & 0.526 \\
\hline Junagadh & 0.641 & 0.606 & 0.577 & 0.569 & 0.646 & 0.560 & 0.527 & 0.605 & 0.582 & 0.690 & 0.680 & 0.643 \\
\hline Kachchh & 0.644 & 0.574 & 0.452 & 0.486 & 0.464 & 0.444 & 0.548 & 0.454 & 0.488 & 0.520 & 0.530 & 0.514 \\
\hline Kheda & 0.531 & 0.494 & 0.393 & 0.431 & 0.478 & 0.407 & 0.373 & 0.434 & 0.428 & 0.567 & 0.574 & 0.554 \\
\hline Mahesana & 0.504 & 0.649 & 0.578 & 0.606 & 0.601 & 0.507 & 0.488 & 0.525 & 0.516 & 0.522 & 0.528 & 0.523 \\
\hline
\end{tabular}




\begin{tabular}{l|l|l|l|l|l|l|l|l|l|l|l|l}
\hline Panchmahals & 0.587 & 0.586 & 0.622 & 0.517 & 0.524 & 0.495 & 0.543 & 0.503 & 0.486 & 0.602 & 0.614 & 0.614 \\
\hline Rajkot & 0.540 & 0.500 & 0.432 & 0.426 & 0.478 & 0.424 & 0.437 & 0.439 & 0.442 & 0.466 & 0.464 & 0.449 \\
\hline Sabarkantha & 0.600 & 0.571 & 0.493 & 0.452 & 0.530 & 0.470 & 0.472 & 0.512 & 0.515 & 0.585 & 0.579 & 0.553 \\
\hline Surat & 0.481 & 0.444 & 0.345 & 0.314 & 0.294 & 0.248 & 0.240 & 0.224 & 0.266 & 0.269 & 0.264 & 0.250 \\
\hline Surendranagar & 0.415 & 0.379 & 0.325 & 0.339 & 0.360 & 0.356 & 0.444 & 0.399 & 0.441 & 0.473 & 0.485 & 0.481 \\
\hline Vadodara & 0.543 & 0.507 & 0.442 & 0.451 & 0.452 & 0.415 & 0.461 & 0.428 & 0.570 & 0.616 & 0.611 & 0.577 \\
\hline Valsad & 0.583 & 0.525 & 0.494 & 0.483 & 0.498 & 0.461 & 0.576 & 0.477 & 0.494 & 0.577 & 0.595 & 0.600 \\
\hline
\end{tabular}

Source: Author's estimation.

Table-A3. Estimated district-wise economic efficiency index (EEI) during 2000-2011

\begin{tabular}{|c|c|c|c|c|c|c|c|c|c|c|c|c|}
\hline District & 2000 & 2001 & 2002 & 2003 & 2004 & 2005 & 2006 & 2007 & 2008 & 2009 & 2010 & 2011 \\
\hline Ahmedabad & 0.327 & 0.294 & 0.259 & 0.304 & 0.380 & 0.389 & 0.344 & 0.306 & 0.321 & 0.324 & 0.372 & 0.319 \\
\hline Amreli & 0.267 & 0.278 & 0.418 & 0.425 & 0.504 & 0.403 & 0.438 & 0.460 & 0.487 & 0.364 & 0.478 & 0.432 \\
\hline Banaskan & 0.378 & 0.396 & 0.367 & 0.426 & 0.479 & 0.451 & 0.413 & 0.404 & 0.399 & 0.360 & 0.466 & 0.386 \\
\hline Bharuch & 0.332 & 0.356 & 0.458 & 0.508 & 0.453 & 0.525 & 0.501 & 0.457 & 0.460 & 0.417 & 0.509 & 0.501 \\
\hline Bhavnagar & 0.289 & 0.211 & 0.309 & 0.372 & 0.348 & 0.349 & 0.373 & 0.364 & 0.394 & 0.346 & 0.367 & 0.391 \\
\hline Dangs & 0.558 & 0.568 & 0.566 & 0.601 & 0.455 & 0.436 & 0.423 & 0.386 & 0.412 & 0.403 & 0.399 & 0.379 \\
\hline Jamnagar & 0.256 & 0.210 & 0.275 & 0.286 & 0.465 & 0.367 & 0.408 & 0.445 & 0.452 & 0.438 & 0.527 & 0.368 \\
\hline Junagadh & 0.347 & 0.413 & 0.459 & 0.442 & 0.539 & 0.468 & 0.451 & 0.442 & 0.465 & 0.450 & 0.486 & 0.379 \\
\hline Kachchh & .368 & 0.370 & 0.383 & 0.406 & 0.436 & 0.416 & 0.338 & 0.356 & 0.370 & 0.339 & 0.408 & 0.301 \\
\hline Kheda & .371 & 0.406 & 0.408 & 0.447 & 0.329 & 0.338 & 0.351 & 0.301 & 0.341 & 0.326 & 0.374 & 0.319 \\
\hline Mahesana & 0.567 & 0.620 & 0.580 & 0.526 & 0.494 & 0.464 & 0.436 & 0.440 & 0.446 & 0.517 & 0.584 & 0.477 \\
\hline Panchmahals & 0.274 & 0.243 & 0.266 & 0.311 & 0.231 & 0.201 & 0.180 & 0.167 & 0.221 & 0.134 & 0.203 & 0.152 \\
\hline Rajkot & 0.262 & 0.196 & 0.339 & 0.352 & 0.574 & 0.516 & 0.501 & 0.445 & 0.500 & 0.394 & 0.507 & 0.408 \\
\hline Sabarkantha & 0.354 & 0.279 & 0.300 & 0.324 & 0.392 & 0.400 & 0.388 & 0.337 & 0.391 & 0.356 & 0.438 & 0.363 \\
\hline Surat & 0.356 & 0.140 & 0.272 & 0.234 & 0.267 & 0.265 & 0.226 & 0.195 & 0.293 & 0.185 & 0.208 & 0.154 \\
\hline Surendranagar & 0.341 & 0.296 & 0.388 & 0.362 & 0.479 & 0.527 & 0.435 & 0.430 & 0.437 & 0.386 & 0.486 & 0.483 \\
\hline Vadodara & 0.285 & 0.239 & 0.299 & 0.331 & 0.346 & 0.338 & 0.298 & 0.269 & 0.314 & 0.278 & 0.349 & 0.283 \\
\hline Valsad & 0.391 & 0.327 & 0.276 & 0.297 & 0.231 & 0.255 & 0.242 & 0.245 & 0.286 & 0.225 & 0.158 & 0.297 \\
\hline
\end{tabular}

Table-A4. Estimated district-wise social equity index (SEI) during 2000-2011

\begin{tabular}{|c|c|c|c|c|c|c|c|c|c|c|c|c|}
\hline District & 2000 & 2001 & 2002 & 2003 & 2004 & 2005 & 2006 & 2007 & 2008 & 2009 & 2010 & 2011 \\
\hline Ahmedabad & 0.753 & 0.822 & 0.817 & 0.765 & 0.766 & 0.770 & 0.876 & 0.772 & 0.720 & 0.702 & 0.728 & 0.693 \\
\hline Amreli & 0.653 & 0.648 & 0.677 & 0.673 & 0.676 & 0.691 & 0.677 & 0.666 & 0.655 & 0.653 & 0.635 & 0.661 \\
\hline Banaskantha & 0.447 & 0.472 & 0.461 & 0.440 & 0.444 & 0.458 & 0.437 & 0.488 & 0.476 & 0.478 & 0.468 & 0.492 \\
\hline Bharuch & 0.696 & 0.726 & 0.725 & 0.722 & 0.727 & 0.739 & 0.770 & 0.735 & 0.728 & 0.739 & 0.747 & 0.746 \\
\hline Bhavnagar & 0.589 & 0.600 & 0.576 & 0.600 & 0.605 & 0.698 & 0.647 & 0.609 & 0.596 & 0.589 & 0.598 & 0.602 \\
\hline Dangs & 0.269 & 0.284 & 0.271 & 0.258 & 0.260 & 0.338 & 0.278 & 0.272 & 0.277 & 0.287 & 0.281 & 0.303 \\
\hline Jamnagar & 0.592 & 0.643 & 0.644 & 0.637 & 0.637 & 0.629 & 0.616 & 0.545 & 0.508 & 0.499 & 0.485 & 0.504 \\
\hline Junagadh & 0.662 & 0.658 & 0.656 & 0.667 & 0.667 & 0.686 & 0.655 & 0.601 & 0.569 & 0.565 & 0.604 & 0.585 \\
\hline Kachchh & 0.516 & 0.473 & 0.519 & 0.495 & 0.497 & 0.616 & 0.580 & 0.536 & 0.507 & 0.501 & 0.492 & 0.528 \\
\hline Kheda & 0.598 & 0.651 & 0.647 & 0.637 & 0.646 & 0.642 & 0.651 & 0.624 & 0.610 & 0.623 & 0.659 & 0.660 \\
\hline Mahesana & 0.765 & 0.815 & 0.812 & 0.821 & 0.825 & 0.886 & 0.830 & 0.799 & 0.779 & 0.779 & 0.785 & 0.794 \\
\hline Panchmahals & 0.461 & 0.427 & 0.420 & 0.435 & 0.443 & 0.459 & 0.486 & 0.520 & 0.506 & 0.509 & 0.535 & 0.561 \\
\hline Rajkot & 0.661 & 0.671 & 0.640 & 0.636 & 0.640 & 0.778 & 0.786 & 0.696 & 0.652 & 0.644 & 0.660 & 0.674 \\
\hline Sabarkantha & 0.684 & 0.728 & 0.725 & 0.715 & 0.720 & 0.715 & 0.597 & 0.665 & 0.687 & 0.711 & 0.727 & 0.711 \\
\hline Surat & 0.642 & 0.671 & 0.655 & 0.663 & 0.672 & 0.781 & 0.772 & 0.697 & 0.673 & 0.677 & 0.687 & 0.730 \\
\hline Surendranagar & 0.455 & 0.503 & 0.470 & 0.457 & 0.459 & 0.492 & 0.466 & 0.441 & 0.437 & 0.455 & 0.474 & 0.448 \\
\hline Vadodara & 0.568 & 0.547 & 0.566 & 0.593 & 0.598 & 0.595 & 0.638 & 0.596 & 0.593 & 0.614 & 0.618 & 0.626 \\
\hline Valsad & 0.606 & 0.618 & 0.612 & 0.614 & 0.620 & 0.590 & 0.647 & 0.602 & 0.579 & 0.576 & 0.547 & 0.583 \\
\hline
\end{tabular}

Source: Author's estimation. 
Appendix: B

Table-B1. Association of SLSI, ESI, EEI and SEI with climatic factors

\begin{tabular}{l|l|l|l|l|l|l|l|l}
\hline Factors & SLSI & ESI & EEI & SEI & maxtwise & maxtspse & maxtsuse & maxtause \\
\hline SLSI & 1 & $0.529^{* *}$ & $0.650^{* *}$ & $0.576^{* *}$ & -0.115 & -0.037 & 0.011 & -0.029 \\
\hline ESI & $0.529^{* *}$ & 1 & $0.259^{* *}$ & $-0.188^{* *}$ & -0.081 & -0.113 & -0.122 & -0.073 \\
\hline EEI & $0.650^{* *}$ & $0.259^{* *}$ & 1 & -0.002 & $-0.248^{* *}$ & $-0.238^{* *}$ & -0.132 & $-0.210^{* *}$ \\
\hline SEI & $0.576^{* *}$ & $-0.188^{* *}$ & -0.002 & 1 & 0.082 & $0.216^{* *}$ & $0.212^{* *}$ & $0.176^{* *}$ \\
\hline maxtwise & -0.115 & -0.081 & $-0.248^{* *}$ & 0.082 & 1 & $0.439^{* *}$ & $0.311^{* *}$ & $0.440^{* *}$ \\
\hline maxtspse & -0.037 & -0.113 & $-0.238^{* *}$ & $0.216^{* *}$ & $0.439^{* *}$ & 1 & $0.341^{* *}$ & -0.064 \\
\hline maxtsuse & 0.011 & -0.122 & -0.132 & $0.212^{* *}$ & $0.311^{* *}$ & $0.341^{*} *$ & 1 & $0.324^{* *}$ \\
\hline maxtause & -0.029 & -0.073 & $-0.210^{* *}$ & $0.176^{* *}$ & $0.440^{* *}$ & -0.064 & $0.324^{* *}$ & 1 \\
\hline mintwise & -0.124 & -0.037 & -0.129 & -0.057 & $0.591^{* *}$ & $-0.213^{* *}$ & -0.013 & $0.345^{* *}$ \\
\hline mintspse & 0.011 & 0.024 & $-0.192^{* *}$ & $0.145^{*}$ & $0.333^{* *}$ & -0.058 & -0.015 & $0.316^{* *}$ \\
\hline mintsuse & 0.076 & -0.026 & -0.036 & $0.160^{*}$ & $0.140^{*}$ & $-0.412^{* *}$ & 0.065 & $0.343^{* *}$ \\
\hline mintause & -0.023 & 0.053 & -0.068 & -0.024 & $0.253^{* *}$ & $-0.508^{* *}$ & $-0.218^{* *}$ & $0.382^{* *}$ \\
\hline pcpwise & $0.220^{* *}$ & 0.111 & $0.235^{* *}$ & 0.061 & -0.089 & 0.025 & -0.047 & -0.074 \\
\hline pcpspse & $-0.138^{*}$ & $-0.170^{*}$ & -0.07 & -0.02 & $0.260^{* *}$ & 0.038 & 0.044 & $0.306^{* *}$ \\
\hline pcpause & $-0.165^{*}$ & -0.041 & $-0.206^{* *}$ & -0.056 & $0.551^{* *}$ & $0.200^{* *}$ & $-0.207^{* *}$ & 0.022 \\
\hline pcpause & $-0.160^{*}$ & $0.142^{*}$ & -0.091 & $-0.278^{* *}$ & $0.413^{* *}$ & 0.065 & 0.019 & -0.124 \\
\hline So
\end{tabular}

Source: Author's estimation. *and*** shows that correlation coefficients are statistically significant at 0.05 and 0.01 significance level.

Table-B1. Association of SLSI, ESI, EEI and SEI with climatic factors Conti...

\begin{tabular}{|c|c|c|c|c|c|c|c|c|}
\hline Factors & mintwise & mintspse & mintsuse & mintause & pcpwise & pcpspse & pcpause & pcpause \\
\hline SLSI & -0.124 & 0.011 & 0.076 & -0.023 & $0.220^{* *}$ & $-0.138^{*}$ & $-0.165^{*}$ & $-0.160^{*}$ \\
\hline$E S I$ & -0.037 & 0.024 & -0.026 & 0.053 & 0.111 & $-0.170^{*}$ & -0.041 & $0.142^{*}$ \\
\hline EEI & -0.129 & $-0.192^{* *}$ & -0.036 & -0.068 & $0.235^{* *}$ & -0.07 & $-0.206^{* *}$ & -0.091 \\
\hline$S E I$ & -0.057 & $0.145^{*}$ & $0.160^{*}$ & -0.024 & 0.061 & -0.02 & -0.056 & $-0.278^{*} *$ \\
\hline maxtwise & 0.591** & $0.333^{* *}$ & $0.140^{*}$ & $0.253^{* *}$ & -0.089 & $0.260^{* *}$ & $0.551^{* *}$ & $0.413^{* *}$ \\
\hline maxtspse & $-0.213 * *$ & -0.058 & $-0.412 * *$ & $-0.508^{*} *$ & 0.025 & 0.038 & $0.200 * *$ & 0.065 \\
\hline maxtsuse & -0.013 & -0.015 & 0.065 & $-0.218^{*} *$ & -0.047 & 0.044 & $-0.207 * *$ & 0.019 \\
\hline maxtause & $0.345^{* *}$ & $0.316^{* *}$ & $0.343^{* *}$ & $0.382^{* *}$ & -0.074 & $0.306^{* *}$ & 0.022 & -0.124 \\
\hline mintwise & 1 & $0.698^{* *}$ & $0.729^{* *}$ & $0.777^{*} *$ & $-0.149^{*}$ & $0.149^{*}$ & $0.391 * *$ & $0.333^{* *}$ \\
\hline mintspse & 0.698** & 1 & $0.779^{* *}$ & $0.758^{* *}$ & $-0.176^{* *}$ & -0.132 & 0.123 & 0.129 \\
\hline mintsuse & $0.729^{* * *}$ & $0.779^{* *}$ & 1 & $0.856^{* *}$ & $-0.184^{*} *$ & -0.091 & 0.009 & -0.021 \\
\hline mintause & $0.777^{*} *$ & $0.758^{* *}$ & $0.856^{* *}$ & 1 & $-0.179^{* *}$ & -0.083 & $0.173^{*}$ & $0.149^{*}$ \\
\hline pcproise & $-0.149^{*}$ & $-0.176 * *$ & $-0.184 * *$ & $-0.179 * *$ & 1 & 0.057 & -0.059 & -0.004 \\
\hline pcpspse & $0.149^{*}$ & -0.132 & -0.091 & -0.083 & 0.057 & 1 & $0.308^{*} *$ & 0.017 \\
\hline pcpause & 0.391** & 0.123 & 0.009 & $0.173^{*}$ & -0.059 & $0.308^{*} *$ & 1 & $0.419^{* * *}$ \\
\hline pcpause & 0.333*** & 0.129 & -0.021 & $0.149^{*}$ & -0.004 & 0.017 & $0.419^{* *}$ & 1 \\
\hline
\end{tabular}

Source: Author's estimation. *and** shows that correlation coefficients are statistically significant at 0.05 and 0.01 significance level.

\section{Appendix: C}

Table-C1. Association of SLSI, ESI, EEI and SEI with socio-economics factors

\begin{tabular}{|c|c|c|c|c|c|c|c|c|c|c|c|}
\hline Factors & SLSI & $E S I$ & $E E I$ & SEI & $P D$ & $P G R$ & $F A G C A$ & $U R$ & $C I$ & $H H T$ & РCAMP \\
\hline$\overline{S L S I}$ & 1 & $0.529 * *$ & $0.650^{* * *}$ & $0.576^{* *}$ & $-0.360^{* *}$ & $-0.559^{* *}$ & $-0.229^{* *}$ & $-0.144^{*}$ & 0.127 & $0.161^{*}$ & -0.014 \\
\hline$E S I$ & 529 ** & 1 & $0.259^{* *}$ & $-0.188^{*} *$ & $-0.592^{* *}$ & $-0.491^{*} *$ & $0.260 * *$ & $-0.620^{*} *$ & 0.082 & $-0.408^{*} *$ & $0.288^{*} * *$ \\
\hline$E E I$ & $0.650^{* * *}$ & $0.259^{* *}$ & 1 & & $-0.483^{*} *$ & $-0.362^{*} *$ & $-0.296^{* *}$ & $-0.287^{* *}$ & 0.082 & -0.097 & $0.387^{* *}$ \\
\hline SEI & $0.576^{* *}$ & $-0.188^{* *}$ & -0.002 & 1 & $0.294 * *$ & $-0.171^{*}$ & $-0.313^{* * *}$ & $0.485^{*} *$ & 0.062 & $0.628^{*} *$ & $-0.538^{*} *$ \\
\hline$\overline{P D}$ & $-0.360^{* *}$ & $-0.592^{* *}$ & $-0.483^{*} *$ & & 1 & $0.235^{* * *}$ & 0.052 & $0.502^{*} *$ & -0.011 & 0.394** & $-0.364 * *$ \\
\hline $\begin{array}{l}P G R \\
\end{array}$ & $-0.559^{* *}$ & -0.491 *** & $-0.362^{* *}$ & $-0.171^{*}$ & $0.235^{*} *$ & 1 & $0.340^{*} *$ & $0.391^{*} *$ & -0.002 & $0.192^{*} *$ & 36 \\
\hline FAGCA & $-0.229 * *$ & $0.260^{*} *$ & $-0.296^{* *}$ & $-0.313^{*} *$ & 0.052 & $0.340^{*} *$ & 1 & $-0.260^{* *}$ & 0.105 & $-0.239 * *$ & $0.147^{*}$ \\
\hline UR & $-0.144^{*}$ & $-0.620^{* *}$ & $-0.287 * *$ & $0.485^{*} *$ & $0.502 * *$ & 0.391 ** & $-0.260^{* *}$ & 1 & -0.016 & $0.895^{*} *$ & $-0.601 * *$ \\
\hline$C I$ & 0.127 & 0.082 & 0.082 & 0.062 & -0.011 & -0. & 0.105 & -0.0 & 1 & 0. & -0.074 \\
\hline HHT & $0.161^{*}$ & $-0.408 * *$ & -0.097 & $0.628^{*} *$ & 0.394 *** & O.192*** & $-0.239 * *$ & $0.895^{*} *$ & 0.005 & 1 & $-0.557 * *$ \\
\hline PCAMP & -0.014 & $0.288^{*} *$ & $0.387^{*} *$ & $-0.538^{* *}$ & $-0.364 * *$ & -0.036 & $0.147^{*}$ & $-0.601 * *$ & -0.074 & $-0.557 * *$ & 1 \\
\hline$F G Y$ & $0.308 * *$ & 0.106 & $0.262^{*} *$ & $0.174^{*}$ & -0.052 & -0.100 & -0.019 & $0.156^{*}$ & -0.032 & $0.313^{* * *}$ & -0.105 \\
\hline GIAGCA & $0.136^{*}$ & -0.057 & 0.081 & $0.183^{*} *$ & 0.082 & 0.044 & -0.072 & 0.071 & $0.476^{*} *$ & 0.08 & -0 . \\
\hline FCPHL & 0.045 & $-0.134^{*}$ & -0.054 & $0.211 * *$ & $0.201 * *$ & 0.093 & -0.003 & $0.156^{*}$ & $0.414 * *$ & 0. & $66^{*}$ \\
\hline$P C D D P$ & $0.383^{* *}$ & $0.186^{* *}$ & o.499** & 0.041 & $-0.182 * *$ & $-0.279^{* *}$ & $-0.220^{*} *$ & -0.03 & -0.013 & $0.174^{*}$ & 0.037 \\
\hline AOPHL & $0.267 * *$ & 0.031 & $0.362^{*} *$ & 0.093 & -0.100 & $-0.220^{*} *$ & $-0.252^{*} *$ & 0.032 & 0.411 ** & 0.087 & -0.038 \\
\hline$\underline{L R}$ & $0.312^{*} *$ & $-0.321 * *$ & -0.073 & $0.767 * *$ & $0.511^{*} *$ & -0.057 & $-0.237^{*} *$ & $0.657^{*} *$ & 0.009 & $0.717^{*} *$ & $-0.399^{* *}$ \\
\hline FLR & $0.291 * *$ & $-0.294 * *$ & -0.054 & $0.700^{*} *$ & $0.470^{*} *$ & -0.026 & $-0.181 * *$ & $0.695 * *$ & 0.011 & $0.789^{*} *$ & $-0.348^{*} *$ \\
\hline HHEA & 0.271 ** & $-0.240^{* *}$ & -0.084 & $0.651^{*} *$ & $0.246^{* *}$ & -0.127 & $-0.244^{*} *$ & $0.643^{* *}$ & 0.009 & $0.752^{*} *$ & $-0.646^{* * *}$ \\
\hline PHASW & $0.403^{*} *$ & $-0.221 * *$ & 0.033 & $0.743^{*} *$ & $0.236^{* *}$ & 0.015 & $-0.372 * *$ & $0.540^{* * *}$ & 0.008 & $0.703^{*} *$ & $-0.442^{*} *$ \\
\hline IMR & $-0.247 * *$ & $-0.497 * *$ & $-0.232^{*} *$ & o.196** & $0.412^{* *}$ & $0.276^{* *}$ & -0.185** & $0.715^{* *}$ & 0.009 & 0.597 *** & $-0.513^{* *}$ \\
\hline$B R$ & $0.152^{*}$ & $0.267 * *$ & -0.086 & 0.085 & $-0.160^{*}$ & $-0.155^{*}$ & 0.003 & $-0.346^{* *}$ & -0.077 & $-0.294 * *$ & 0.026 \\
\hline
\end{tabular}


Table-C1. Association of SLSI, ESI, EEI and SEI with socio-economics factors Conti.

\begin{tabular}{|c|c|c|c|c|c|c|c|c|c|c|c|}
\hline Factors & $F G Y$ & $G I A G C A$ & FCPHL & PCDDP & AOPHL & $L R$ & $F L R$ & HHEA & PHASW & IMR & $B R$ \\
\hline SLSI & $0.308^{*} *$ & 0.136* & 0.045 & $0.383 * *$ & $0.267^{*} *$ & $0.312^{* *}$ & $0.291 * *$ & $0.271 * *$ & $0.403 * *$ & $-0.247^{* *}$ & $0.152^{*}$ \\
\hline$E S I$ & 0.106 & -0.057 & $-0.134^{*}$ & $0.186^{* *}$ & 0.031 & $-0.321^{* *}$ & $-0.294^{* *}$ & $-0.240^{* *}$ & $-0.221^{* *}$ & $-0.497^{*} *$ & $0.267^{*} *$ \\
\hline$E E I$ & $0.262^{*} *$ & 0.081 & -0.054 & 0.499** & $0.362^{*} *$ & -0.073 & -0.054 & -0.084 & 0.033 & $-0.232 * *$ & -0.086 \\
\hline SEI & $0.174^{*}$ & $0.183^{*} * *$ & 0.211 *** & 0.041 & 0.093 & 0.767 *** & $0.700^{*} * *$ & $0.651 * *$ & $0.743 * *$ & 0.196**⿻丷木 & 0.085 \\
\hline$P D$ & -0.052 & 0.082 & 0.201 *** & $-0.182^{* *}$ & -0.100 & $0.511^{*} *$ & $0.470^{*} *$ & $0.246 * *$ & $0.236^{* *}$ & $0.412^{* *}$ & $-0.160^{*}$ \\
\hline$P G R$ & -0.1 & 0.044 & 0.093 & $-0.279 * *$ & $-0.220^{*} *$ & -0.057 & -0.026 & -0.127 & 0.015 & $0.276^{* *}$ & $-0.155^{*}$ \\
\hline$F A G C A$ & -0.019 & -0.072 & -0.003 & $-0.220 * *$ & $-0.252^{*} *$ & $-0.237 * *$ & $-0.181^{*} *$ & $-0.244^{*} *$ & $-0.372^{* *}$ & $-0.185^{*} *$ & 0.003 \\
\hline$U R$ & $0.156^{*}$ & 0.071 & $0.156^{*}$ & -0.03 & 0.032 & $0.657 * *$ & 0.695** & $0.643 * *$ & $0.540^{*} *$ & $0.715^{* *}$ & $-0.346^{*} *$ \\
\hline$C I$ & -0.032 & $0.476^{* * *}$ & 0.414 *** & -0.013 & 0.411 *** & 0.009 & 0.011 & 0.009 & 0.008 & 0.009 & -0.077 \\
\hline$H H T$ & $0.313^{*} *$ & 0.08 & $0.149^{*}$ & $0.174 *$ & 0.087 & 0.717 ** & $0.789^{* *}$ & $0.752 * *$ & $0.703^{*} *$ & $0.597 * *$ & $-0.294^{*} *$ \\
\hline PCAMP & -0.105 & -0.105 & $-0.166^{*}$ & 0.037 & -0.038 & $-0.399 * *$ & $-0.348 * *$ & -0.646 ** & $-0.442^{* *}$ & $-0.513 * *$ & 0.026 \\
\hline$F G Y$ & 1 & -0.05 & 0.008 & 0.417 ** & 0.072 & $0.164 *$ & $0.257^{*} *$ & $0.367 * *$ & $0.210^{*} *$ & 0.108 & -0.075 \\
\hline$G I A G C A$ & -0.05 & 1 & $0.870^{*} * *$ & -0.098 & $0.642 * *$ & $0.144 *$ & 0.101 & 0.035 & 0.237 *** & 0.088 & 0.054 \\
\hline FCPHL & 0.008 & $0.870^{* * *}$ & 1 & -0.072 & $0.583^{*} *$ & $0.230^{* * *}$ & $0.204 * *$ & 0.13 & $0.219^{* * *}$ & $0.137^{*}$ & 0.024 \\
\hline PCDDP & $0.417^{*} *$ & -0.098 & -0.072 & 1 & $0.135^{*}$ & 0.053 & $0.145^{*}$ & $0.177 * *$ & $0.156^{*}$ & -0.077 & -0.041 \\
\hline$A O P H L$ & 0.072 & $0.642^{*} *$ & $0.583^{*} *$ & $0.135^{*}$ & 1 & 0.067 & 0.071 & $0.165^{*}$ & 0.126 & 0.021 & 0.035 \\
\hline$L R$ & $0.164 *$ & $0.144^{*}$ & $0.230^{* * *}$ & 0.053 & 0.067 & 1 & $0.970^{* * *}$ & $0.532 * *$ & 0.584*** & $0.457^{*} *$ & -0.341 *** \\
\hline$F L R$ & $0.257^{*} *$ & 0.101 & $0.204 * *$ & $0.145^{*}$ & 0.071 & $0.970^{* * *}$ & 1 & $0.588 * *$ & $0.585^{* *}$ & 0.469** & $-0.390^{*} *$ \\
\hline HHE $A$ & $0.367^{*} * *$ & 0.035 & 0.13 & $0.177^{*} *$ & $0.165^{*}$ & 0.532** & 0.588** & 1 & $0.515^{* * *}$ & $0.412^{* *}$ & -0.038 \\
\hline$P H A S W$ & $0.210^{* * *}$ & $0.237^{*} *$ & $0.219^{* *}$ & $0.156^{*}$ & 0.126 & $0.584 * *$ & $0.585^{* *}$ & $0.515^{* *}$ & 1 & 0.394** & 0.104 \\
\hline$I M R$ & 0.108 & 0.088 & $0.137^{*}$ & -0.077 & 0.021 & $0.457 * *$ & $0.469 * *$ & $0.412^{*} *$ & $0.394 * *$ & 1 & $-0.332^{*} *$ \\
\hline$B R$ & -0.075 & 0.054 & 0.024 & -0.041 & 0.035 & $-0.341 * *$ & $-0.390 * *$ & -0.038 & 0.104 & $-0.332 * *$ & 1 \\
\hline
\end{tabular}

Source: Author's estimation. *and*** shows that correlation coefficients are statistically significant at 0.05 and 0.01 significance level. 